Review

\title{
Hepatic Stellate Cell Activation and Inactivation in NASH-Fibrosis-Roles as Putative Treatment Targets?
}

\author{
Alexandra Zisser ${ }^{1}$, David H. Ipsen ${ }^{2}$ and Pernille Tveden-Nyborg ${ }^{1, *(D)}$ \\ 1 Department of Veterinary and Animal Sciences, Faculty of Health and Medical Sciences, University of \\ Copenhagen, Ridebanevej 9, 1870 Frederiksberg C, Denmark; alexandra.zisser@sund.ku.dk \\ 2 Liver Disease Research, Novo Nordisk A/S, Novo Nordisk Park 1, 2760 Måløv, Denmark; \\ DVIE@novonordisk.com \\ * Correspondence: ptn@sund.ku.dk
}

check for updates

Citation: Zisser, A.; Ipsen, D.H.; Tveden-Nyborg, P. Hepatic Stellate Cell Activation and Inactivation in NASH-Fibrosis-Roles as Putative Treatment Targets? Biomedicines 2021, 9, 365. https://doi.org/10.3390/ biomedicines 9040365

Academic Editor: Shaker Mousa

Received: 15 March 2021

Accepted: 27 March 2021

Published: 31 March 2021

Publisher's Note: MDPI stays neutral with regard to jurisdictional claims in published maps and institutional affiliations.

Copyright: (c) 2021 by the authors. Licensee MDPI, Basel, Switzerland. This article is an open access article distributed under the terms and conditions of the Creative Commons Attribution (CC BY) license (https:// creativecommons.org/licenses/by/ $4.0 /)$.

\begin{abstract}
Hepatic fibrosis is the primary predictor of mortality in patients with non-alcoholic steatohepatitis (NASH). In this process, the activated hepatic stellate cells (HSCs) constitute the principal cells responsible for the deposition of a fibrous extracellular matrix, thereby driving the hepatic scarring. HSC activation, migration, and proliferation are controlled by a complex signaling network involving growth factors, lipotoxicity, inflammation, and cellular stress. Conversely, the clearance of activated HSCs is a prerequisite for the resolution of the extracellular fibrosis. Hence, pathways regulating the fate of the HSCs may represent attractive therapeutic targets for the treatment and prevention of NASH-associated hepatic fibrosis. However, the development of anti-fibrotic drugs for NASH patients has not yet resulted in clinically approved therapeutics, underscoring the complex biology and challenges involved when targeting the intricate cellular signaling mechanisms. This narrative review investigated the mechanisms of activation and inactivation of HSCs with a focus on NASH-associated hepatic fibrosis. Presenting an updated overview, this review highlights key cellular pathways with potential value for the development of future treatment modalities.
\end{abstract}

Keywords: non-alcoholic fatty liver disease; non-alcoholic steatohepatitis; fibrosis; hepatic stellate cells; HSC activation; HSC inactivation

\section{Introduction}

Around a quarter of the world's adult population are predicted to have non-alcoholic fatty liver disease (NAFLD) [1]. An estimated 7-30\% of these patients develop nonalcoholic steatohepatitis (NASH), characterized by progressing inflammation and fibrosis that compromise liver function and patient health [1,2]. Hepatic fibrosis constitutes a primary predictor of mortality and adverse liver events in NAFLD patients, and it is caused by the activation of liver resident myofibroblasts that primarily consist of hepatic stellate cells (HSCs) and a smaller population of portal myofibroblasts, resulting in the subsequent deposition of a fibrous extracellular matrix (ECM) central to NASH-related fibrosis [3-6]. Just as HSC activation is a key event in the development and progression of hepatic fibrosis, the elimination of activated HSCs (aHSCs) is pivotal for fibrosis resolution [7]. In this way, HSCs represent an attractive therapeutic target against advanced NASH; however, the cellular mechanisms underlying HSC activation and elimination in the liver remain to be fully elucidated [8,9]. This narrative review provides an update on the mechanisms involved in the regulation of HSCs and their putative role in the current treatment modalities of NASH-related fibrosis.

\section{NAFLD Etiology and the Role of Hepatic Stellate Cells}

NAFLD defines a spectrum of liver diseases characterized by hepatic steatosis not due to excessive alcohol consumption [10]. Multiple factors are involved NAFLD development and progression; however, dyslipidemia is a central feature in most patients. An excessive 
intake of energy in the form of fat and carbohydrates results in the hepatic accumulation of lipids and lipotoxicity [11]. Continued fatty acid oxidation generates increased levels of reactive oxidant species and cytotoxic lipid metabolites, which promote oxidative and lipotoxic stress that lead to cellular damage and inflammation, hallmarking the progression from simple steatosis to NASH (defined by hepatic steatosis, inflammation, and the presence of ballooning hepatocytes) [11,12]. Infiltrating immune cells, together with liverresident macrophages (Kupffer cells), secrete pro-inflammatory and -fibrotic cytokines that drive the inflammation and create a self-propagating vicious circle of hepatocellular stress and damage $[7,13]$ (a brief, schematic overview of general mechanisms is shown in Figure 1). The crosstalk between inflammation, growth factors, nuclear receptor signaling, ECM interactions, and metabolic signals promotes the activation of HSCs and portal myofibroblasts, leading to hepatic scarring/fibrosis and ultimately compromising hepatic function, as described in detail later in the manuscript $[3,14]$. This activation induces the production of fibrous collagens and stimulates the proliferation and migration of HSCs and portal myofibroblasts, thus allowing for the advancement of the fibrous ECM. The fibrosis of the hepatic parenchyma commonly begins perivenularly in zone 3 (stage F1), progresses to portal and periportal areas (stage F2), and can advance to bridging fibrosis (stage F3) and cirrhosis (stage F4), ultimately showing severe structural changes in liver morphology and deviated angiogenesis $[15,16]$. In addition to HSC activation, myofibroblasts residing in the portal area are activated to produce a fibrous ECM. In this regard, the portal myofibroblasts resemble HSCs but do not express the same surface markers or carry vitamin A droplets $[17,18]$. Portal myofibroblasts are situated around the bile ducts, and the concurrent deposition of a fibrotic ECM is linked to cholangiocytes (bile duct epithelia) and fibrosis of the biliary system, e.g., cholestatic fibrosis, also reported in NASH [6,18]. Hepatic fibrosis increases all-cause mortality, liver-related mortality, and the risk of liver transplantation in patients with NASH [4].

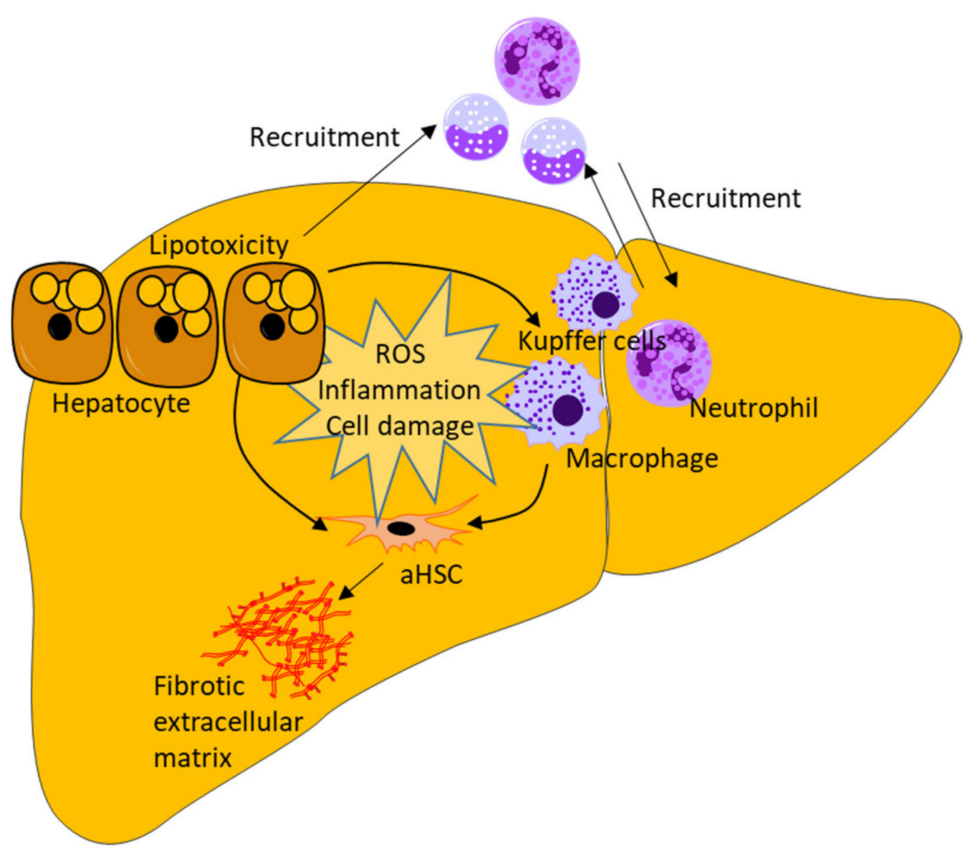

Figure 1. A simplified overview of primary drivers of non-alcoholic steatohepatitis (NASH)-induced hepatic fibrosis. The excessive accumulation of triglycerides and free fatty acids increases hepatocellular lipid oxidation generating reactive oxygen species (ROS) and lipotoxicity. This leads to cellular damage and the release of inflammatory cytokines, prompting the activation of resident liver macrophages (Kupffer cells) and the recruitment of circulating immune cells: monocytes and leukocytes. The initial hepatic steatosis then becomes a state of hepatic inflammation and progresses 
to NASH. The inflammation and sustained lipotoxicity maintain a self-perpetuating vicious circle of increased production of ROS, inflammation, and cell damage, ultimately promoting the activation of hepatic stellate cells (aHSC), which leads to the formation of a fibrogenic extracellular matrix, thus hallmarking the transition to a state of NASH-induced fibrosis.

HSCs account for roughly $10 \%$ of all liver cells and reside in the space of Disse (the perisinusoidal space), lying between hepatocytes and with cellular extensions surrounding the sinusoidal endothelium that maintain consistent exposure to hepatic blood flow [19]. In their dormant state, HSCs display a quiescent, non-proliferative phenotype (qHSCs) and are characterized by storing retinyl esters (vitamin A), cholesteryl esters, and triglycerides in cytosolic lipid vacuoles [20,21]. qHSCs are thought to contribute to ECM homeostasis, hepatocyte proliferation, innate immunity, and sinusoidal blood flow regulation [22,23]. Upon liver injury, qHSCs become activated and transdifferentiate into aHSCs (myofibroblasts), losing their lipid storage droplets and exhibiting a contractile, proliferative, and fibrogenic phenotype, together with vast changes in the gene expression profile [24-27] (Figure 2).

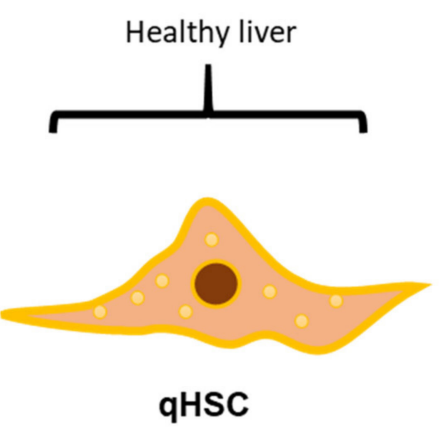

qHSC markers:
Retinyl esters
PPAR
GFAP
BAMBI
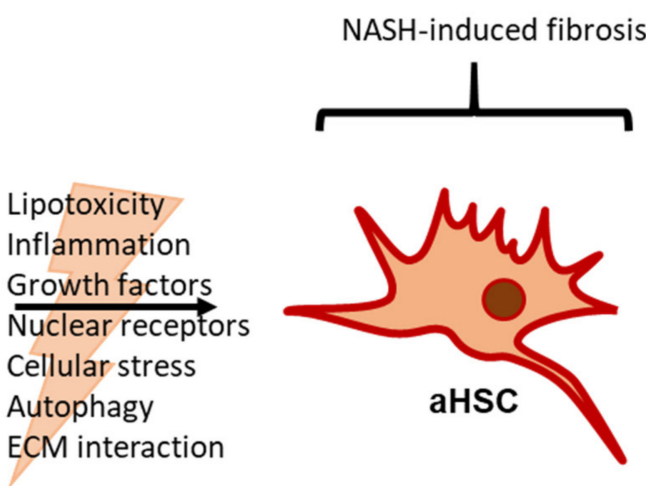

aHSC markers:

Type I collagens $\alpha \mathrm{SMA}$

S100A6

PDGFR $\beta$

TIMP1

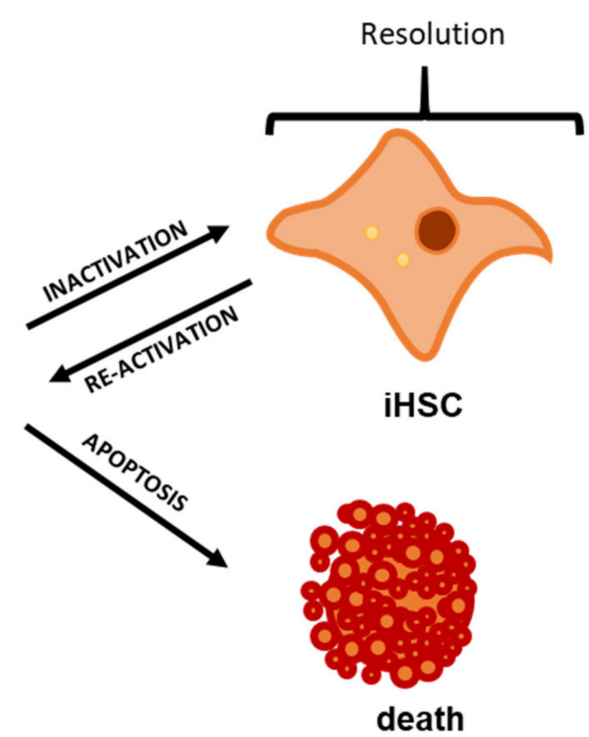

Figure 2. The hepatic stellate cell phenotypic switch in NASH. In a healthy liver, the hepatic stellate cell (HSC) rests in a quiescent state (qHSC) while residing close to the hepatic sinusoids. qHSCs are considered dormant and non-proliferative, and they are characterized by the cytoplasmatic storage of retinyl esters (vitamin A) in lipid droplets; markers include PPAR $\gamma$, GFAP, and BAMBI, all expressed in the qHSCs. The accumulation of lipotoxic metabolites, inflammation, and oxidative stress in NASH affects multiple hepatic cell types and leads to the release/activation of several cellular signaling factors, such as growth factors (e.g., increased TGF $\beta$, PDGF, and connective tissue growth factors) and nuclear receptors (e.g., decreased PPAR $\gamma$ and retinoid X receptor activation), thus promoting an HSC phenotypic switch. In this process, qHSCs lose their stored retinyl esters and transdifferentiate into the activated, proliferative, and contractile state (aHSC). aHSCs are characterized by the production of pro-collagens for extracellular matrix deposition and the promotion of HSC activation and fibrogenesis (thus creating a positive feedback loop), as well as the ability to migrate and divide; markers include the expression of $\alpha$ SMA, S100a6, PDGFR $\beta$, and TIMP1. The clearance of aHSCs is necessary for the cessation of matrix deposition, and it can take place through apoptosis or through inactivation. Inactivated HSCs (iHSCs) differentiate towards a more dormant phenotype (e.g., with a decrease of aHSC characteristics and the re-establishment of the cytoplasmic storage of retinyl esters), but they do not completely revert to the qHSC state and have increased sensitivity toward reactivation. aHSC: activated hepatic stellate cell; BAMBI: bone morphogenetic protein and activin membrane bound inhibitor; ECM: extracellular matrix; GFAP: glial fibrillary acidic protein; iHSC: inactivated hepatic stellate cell; PDGFR $\beta$ : platelet derived growth factor receptor $\beta$; PPAR $\gamma$ : peroxisome proliferator activated receptor $\gamma$; qHSC: quiescent hepatic stellate cell; S100a6: S100 calcium-binding protein A6; TGF $\beta$ : transforming growth factor beta; TIMP1: tissue inhibitor of metalloproteinase 1; $\alpha \mathrm{SMA}$ : alpha smooth muscle actin. 
The contractile activity of aHSCs is characterized by the expression of alpha smooth muscle actin ( $\alpha$ SMA; encoded by Acta2) and S100a6 (S100 calcium-binding protein A6), the formation of stress fibers, and the deposition of ECM components [28]. Fibrillary collagens (e.g., collagen type I, which is encoded by Col1a1 and Col1a2) in the space of Disse cause sinusoidal capillarization, altering the fenestrated liver sinusoidal endothelial cell (LSEC) phenotype to a more defined vascular basement membrane $[29,30]$. The transformation of the sinusoids interferes with the molecular exchange between sinusoidal blood and hepatocytes, thereby compromising liver metabolism [29,30]. By secreting pro-fibrotic cytokines, aHSCs promote fibrosis generation, and, in turn, interaction with the fibrotic tissue activates HSCs [31]. Moreover, aHSCs suppress the resolution of the fibrotic ECM through changes in matrix metalloproteinase activity and the upregulation of the tissue inhibitors of metalloproteinase levels [32]. In this way, the activation of HSCs and the subsequent deposition of a fibrotic ECM creates a positive feedback loop, in which HSCs maintain a perpetually active state as chronic injury progresses [14] (Figure 2). Recently, single-cell RNA-sequencing revealed the distinct spatial zonation of HSCs, which can be designated as portal vein- or central vein-associated HSCs characterized by a high expression of nerve growth factor and ADAMTS-like 2 (a disintegrin and metalloproteinase with thrombospondin), respectively [33]. Central vein-associated HSCs were found to be the dominant source of collagen in $\mathrm{CCl}_{4}$-induced centrilobular fibrosis, and targeting these cells inhibited hepatic fibrosis [33]. As NASH is often characterized by centrilobular fibrosis, the zonation of HSCs and ability to target central vein-associated HSCs may have important consequences for the future development of precision medicine. Despite the initial centrilobular injury, NASH eventually involves most of the liver parenchyma, cholangiocytes, and hepatic progenitor cells that also play important roles in HSC activation. Chronic lipotoxic liver injury leads to hepatocyte senescence, which promotes cholangiocyte/progenitor cell proliferation and forms the so-called ductular reaction [5,34]. The reactive ducts secrete a range of pro-fibrotic factors (e.g., platelet-derived growth factor (PDGF) and transforming growth factor beta (TGF $\beta)$ ) and correlate with fibrosis severity $[5,35]$. Consequently, blocking cholangiocyte secretin-signaling was found to reduce liver fibrosis by decreasing TGF $\beta$-signaling [36]. This underscores the complexity of the cellular networks and crosstalk involved in HSCs in NASH.

Once injury ceases, fibrosis may resolve. Fibrosis regression is facilitated by ECM remodeling to remove scarring and re-establish a functional liver structure, and it requires a decrease in aHSCs [37]. During fibrosis regression, aHSCs are cleared through apoptosis or by becoming inactivated (iHSCs), reverting to a quiescent-like phenotype with a distinguishable gene expression profile more similar to qHSCs than aHSCs and with a lower threshold for re-activation in vivo [38,39] (Figure 2).

\section{Mechanisms of HSC Activation}

\subsection{Lipotoxicity and Inflammation}

The excess lipid and cholesterol accumulation in hepatocytes can cause lipotoxicity by generating free radicals, such as reactive oxygen species (ROS), thereby promoting oxidative stress, compromising cellular metabolism and membrane integrity, and leading to decreased organelle function (e.g., mitochondrial dysfunction and endoplasmic reticulum (ER) stress) and the release of pro-inflammatory cytokines [2]. Hepatic cholesterol accumulation can activate HSC directly by stimulating toll-like receptor 4 signaling or indirectly through an uptake of Kupffer cells that subsequently activate HSCs by secreting interleukin IL-1 $\beta$, tumor necrosis factor (TNF), and TGF $\beta[40,41]$ (Figure 3). 


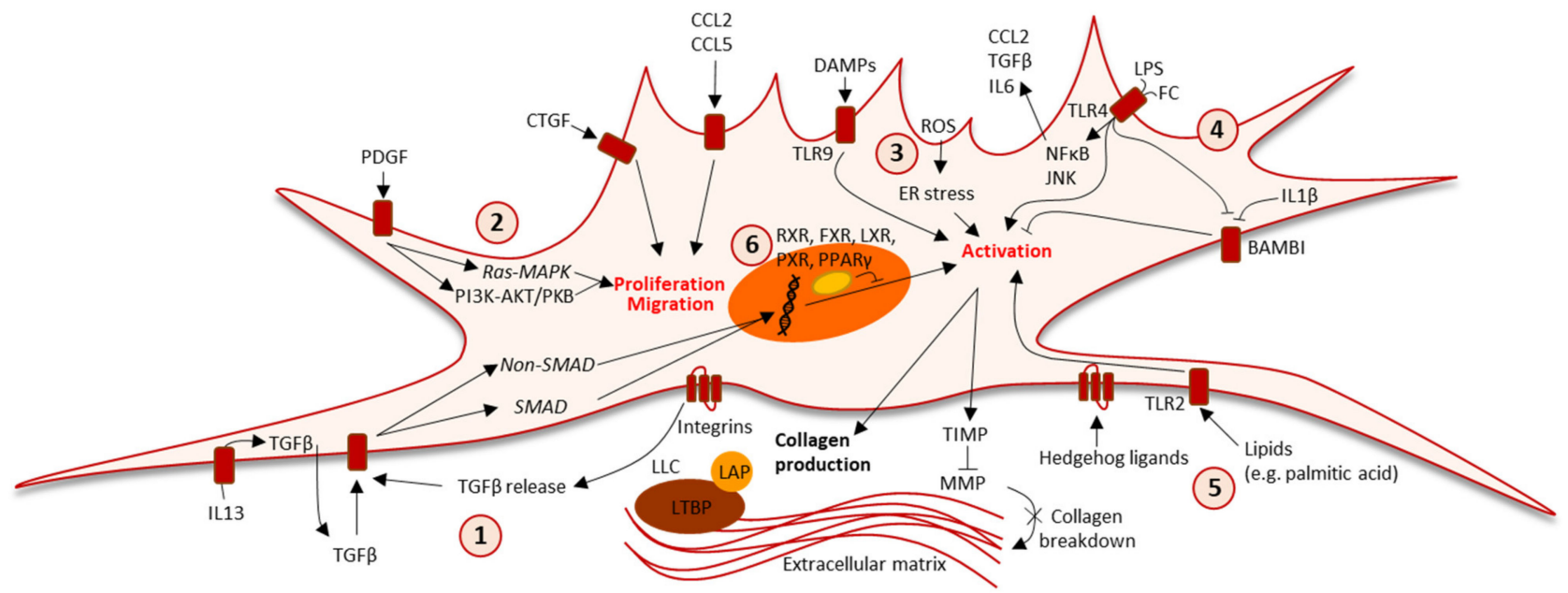

Figure 3. Molecular mechanisms of hepatic stellate cell activation. The activation of hepatic stellate cells involves multiple signaling pathways and receptor systems. 1: TGF $\beta$ is one of the most potent fibrogenic factors and is released in response to insults. In HSCs, TGF $\beta$ is released through IL-13-dependent induction and via integrin-mediated interactions with extracellular TGF $\beta$ stored in a LLC. TGF $\beta$ acts through SMAD and non-SMAD pathways to increase collagen synthesis and extracellular matrix deposition. An increased TIMP level inhibits MMP expression and collagen breakdown. 2: PDGF induces RAS-MAPK and PI3K-AKT/PKB signaling that-alongside cytokines and growth factors such as CCL2, CCL5, and CTGF-promotes HSC proliferation and migration. 3: Increased ROS induce ER stress, which (alongside DAMPs) leads to HSC activation. 4: Gut permeability may increase in NASH, and gut-derived and hepatic FC signaling through TLR4 promotes the production of inflammatory cytokines, growth factors, and HSC activation. In addition, TLR4 signaling can indirectly activate HSCs by decreasing the expression of the TGF $\beta$ decoy receptor BAMBI, which is also decreased by the inflammatory cytokine IL-1 $\beta$. 5: In turn, lipotoxic lipid (e.g., palmitic acid) signaling through TLR2 and Hedgehog-derived signaling further contributes to HSC activation. 6: Nuclear receptors also play an important role in HSC activation, being inhibited by RXR, FXR, LXR, PXR, and PPAR $\gamma$ (decreased in activated HSCs). Though all mechanisms of HSC activation remain to be disclosed, this figure illustrates the highly complex cellular signaling patterns involved in NASHassociated HSC activation and the subsequent production of a fibrous extracellular matrix. AKT/PKB: protein kinase B. CTGF: connective tissue growth factor. BAMBI: bone morphogenetic protein and activin membrane-bound inhibitor. CCL: chemokine C-C motif ligand. DAMP: damage-associated molecular patterns. ER: endoplasmic reticulum. FC: free cholesterol. FXR: farnesoid X receptor. HSC: hepatic stellate cell. IL: interleukin. LPS: lipopolysaccharide. LAP: latency-associated protein. LLC: large latent complex. LTBP: latent TGF- $\beta$-binding protein. LXR: liver X receptor. MAPK: mitogen-activated protein kinase. MMP: matrix metalloproteinase. NAFLD: non-alcoholic fatty liver disease. PDGF: platelet-derived growth factor. PI3K: phosphoinositide 3-kinase. PPAR $\gamma$ : peroxisome proliferator-activated receptor $\gamma$. PXR: pregnane $X$ receptor. ROS: reactive oxygen species. RXR: retinoid $X$ receptor. TIMP: tissue inhibitor of matrix metalloproteinase. TGF $\beta$ : tissue growth factor $\beta$. TLR: toll-like receptor. SMAD: mothers against decapentaplegic homolog. Arrow heads indicate activation, and transversal lines indicate inhibition.

The inflammatory response that is induced in NASH causes circulating monocytes to migrate to the liver, where they-together with the liver resident Kupffer cells-contribute to HSC activation and fibrosis by producing cytokines such as TGF $\beta$, PDGF, TNF, interleukins, and chemokines [14]. TNF and IL-1 $\beta$ promote the survival of aHSCs through the activation of the NFKB pathway [42]. IL-1 $\beta$ exerts its pro-fibrotic function by upregulating tissue inhibitors of metalloproteinase 1 (encoded by Timp1) and downregulating bone morphogenetic proteins and activin membrane-bound inhibitors (a pseudoreceptor for TGF $\beta$ ) in HSCs. In NASH patients, HSCs have been shown to express high levels of the IL-13 receptor, and IL-13 was shown to induce TGF $\beta$ and connective tissue growth factor (CTGF, which is encoded by Ccn2) production in HSCs in vitro [43,44]. Inflammatory chemokines aid HSC activation, and the deletion of chemokine (C-C motif) ligands CCL3 or CCL5 in mice administered $\mathrm{CCl}_{4}$ or a methionine/choline-deficient diet decreased HSC activation, hepatic fibrosis, and immune cell infiltration [45,46]. HSCs also express inflammation-inducing toll-like receptors, inducing activation in response to damage- 
associated molecular patterns released by compromised hepatocytes and ligands such as free fatty acids, lipopolysaccharide, and other microbial products that show elevated serum levels in NAFLD patients due to increased intestinal permeability and dysbiosis [47-49] (Figure 3).

\subsection{Growth Factors}

Hepatic TGF $\beta$ mRNA and serum TGF $\beta$ levels are increased in NASH patients, but a correlation to fibrosis grade is currently disputed [50,51]. TGF $\beta 1$ activation and signaling is induced in response to hepatocellular damage and ROS production, and it is a primary driver of HSC activation [52,53] (Figure 3). TGF $\beta$ is produced by several cell types including aHSCs, and stimulates HSC activation through the mothers against decapentaplegic homolog (SMAD) proteins SMAD2, SMAD3, and SMAD4, in turn inducing type I and III collagen expression and mitogen-activated protein kinase pathways [54-59]. In contrast, TGF $\beta$ induces SMAD7 in qHSCs, which inhibits the production of collagen I and III. This signaling-limiting regulation is absent in aHSCs, thus resulting in permanent TGF $\beta$ mediated activation $[60,61]$. In vivo, the inhibition of TGF $\beta$ signaling was found to reduce HSC activation in a murine NASH model [62]. Latent TGF $\beta$ is stored in the ECM and can be activated through aHSC contraction mediated by integrins (a family of transmembrane receptors expressed by HSCs), subsequently promoting fibrogenesis [63] (Figure 3). Integrins also induce HSC activation through mechanosensing pathways in response to changes in ECM composition, thus enhancing fibrosis and placing integrins as key factors in the propagation of disease $[31,64]$. This role has been confirmed in vivo, where the inhibition of integrins or downstream mechanotransducers reduced $\mathrm{CCl}_{4}$-induced hepatic fibrosis in mice [64-66].

CTGF is a central mediator of TGF $\beta$-dependent fibrogenesis. Expression has been found to be elevated in liver biopsies from NASH patients and serum levels have been found to be positively correlated with fibrosis stage in NAFLD patients, thus underlining a key role in disease and potential application as biomarker [67-69]. CTGF is induced by IL-13, supporting a link between chronic inflammatory signaling and the promotion of fibrosis that is possibly independent of TGF $\beta$-induced signaling [44,70]. CTGF signaling upregulates cellular proliferation and survival, and it promotes the cellular ECM production, migration, and adhesion that are pivotal for aHSCs (Figure 3) [71]. Accordingly, CTGF overexpression was found to induce HSC activation in vivo, whereas its knockdown was found to inhibit aHSCs in vitro and to prevent $\mathrm{CCl}_{4}$-induced fibrosis in vivo [70,72].

PDGF signaling is also linked to HSC activation (Figure 3). The main active isoform PDGFB is produced by aHSCs and infiltrating macrophages, and the overexpression of PDGFB in mice has been found to induce HSC activation and liver fibrosis [73,74]. A central role of PDGF is supported by increased PDGFRA and PDGFD levels in NALFD patients with severe (F3-4) compared to mild (F0-1) fibrosis [75]. Moreover, the hepatic expression of platelet-derived growth factor receptor-beta (PDGFR $\beta$ ) was found to be positively correlated with fibrosis severity in NAFLD patients [76]. PDGFR $\beta$ (encoded by Pdgfrb) is expressed by aHSCs but not qHSCs [77]. The auto-activation of PDGFR $\beta$ in HSCs from $\mathrm{CCl}_{4}$-treated or bile duct-ligated mice was found to accelerate fibrosis, whereas its depletion was found to decrease injury and fibrosis in vivo, supporting a key role in fibrogenesis [78].

PDGF also induces the phosphoinositide 3-kinase/protein kinase B-mediated production of Hedgehog $(\mathrm{Hh})$ ligands in HSCs, while TGF $\beta$ and lipotoxicity stimulate Hh ligand secretion by hepatocytes [79-81]. Hh ligand binding in HSC induces their activation and proliferation while inhibiting apoptosis, making the Hh pathway an important regulator of inflammation and fibrogenesis [82-84] (Figure 3). In NASH patients, Hh activity correlates with aHSC numbers and liver damage severity [85-87]. Inhibiting Hh signaling in Western diet-fed mice with NASH was found to improve fibrosis and hepatic inflammation, supporting a specific role of the Hh pathway in NASH-related fibrosis [88]. Hh signaling might also influence HSC activation by inducing the expression of genes involved in glycolysis and lactate accumulation. This metabolic switch is thought to facilitate the altered gene ex- 
pression profile of aHSCs and is linked to hypoxia-inducible factor-1 alpha expression [89]. The centrilobular distribution of NASH-associated fibrosis is in line with the reduced oxygen tension across the liver-lobule towards the central vein, and it is accompanied by an increased expression of hypoxia-inducible factor- 1 alpha in NASH patients [90,91]. A study in high fat fed mice further indicated a profibrotic role for hypoxia-inducible factor-1 alpha, warranting the future exploration of the effect of hypoxia on HSC fate [92].

\subsection{Nuclear Receptors}

Nuclear receptors such as retinoic acid receptors, liver $X$ receptors, peroxisome proliferator-activated receptors (PPARs), farnesoid $X$ receptors (FXRs), and pregnane $X$ receptors form heterodimers with the retinoid $X$ receptor and modulate gene expression in response to dietary ligands such as cholesterol, fatty acids, and bile acids, all of which are linked to cholesterol metabolism and NAFLD [93,94]. Liver X receptors are nuclear cholesterol sensors, and liver $\mathrm{X}$ receptor alpha positively regulates sterol regulatory element binding protein, which is highly expressed in qHSCs and downregulated during HSC activation [95]. Sterol regulatory element binding protein inhibition was found to increase type I collagen expression in cultured HSCs, whereas liver $X$ receptor ligands were found to suppress HSC activation in vitro [96,97]. HSC-specific PPAR $\gamma$ deletion was shown to aggravate hepatic fibrosis, while PPAR $\gamma$ overexpression decreased HSC activation and fibrosis in vivo $[98,99]$. FXR expression is decreased in NASH patients and inversely correlated with NAFLD activity score [100]. FXR agonists have been found to upregulate PPAR $\gamma$ expression and to decrease activation markers in HSCs in vitro, as well as to reduce hepatic fibrosis in vivo [101-103]. Conversely, high fat fed LDLr-/-/FXR-/- mice were shown to have increased hepatic inflammation and collagen deposition [104]. Polymorphisms of the pregnane $X$ receptor, which is regulated by FXR, have been linked to increased disease severity in NAFLD patients $[105,106]$. Pregnane $X$ receptor agonism inhibited HSC activation in vitro and $\mathrm{CCl}_{4}$-induced liver fibrosis in vivo [107,108] (Figure 3).

\subsection{Cellular Stress and Autophagy}

Increased cellular stress and free radical production play pivotal roles in NAFLDinduced inflammation, TGF $\beta$ activation, and fibrogenesis [53]. Accordingly, antioxidant supplementation (caffeic acid phenethyl ester, sestrin 2, and curcumin) has been shown to decrease HSC activation in vitro and to prevent or ameliorate hepatic fibrosis in rodent models, supporting antioxidants as beneficial in the prevention and potential resolution of disease [109-112].

Reactive oxidant species also promote ER stress in HSCs, which, in turn, stimulates autophagy and HSC activation, and proteins associated with ER stress and autophagy are commonly dysregulated in NAFLD patients $[113,114]$ (Figure 3). Inhibiting autophagy has been found to attenuate HSC activation and proliferation in vitro, as well as to reduce fibrosis in thioacetamide- or $\mathrm{CCl}_{4}$-treated mice $[115,116]$. Autophagy also plays a role in HSC activation because the activated cells decrease their stored retinoid droplets $[117,118]$. However, genetically modified mice incapable of storing retinoids in HSCs showed no difference in fibrosis severity in response to bile duct ligation or $\mathrm{CCl}_{4}$ treatment [119]. In contrast, the application of retinoids suppressed HSC activation in vitro and reduced fibrosis in $\mathrm{CCl}_{4}$-treated animal models [120-122]. Thus, the significance of HSC retinoid autophagy is still unclear. Conversely, ER stress may also increase aHSC clearance by increasing apoptosis and, in turn, reducing fibrogenesis, suggesting differential effects of induced ER stress in HSCs [123].

\section{HSC Inactivation and Apoptosis}

While HSC activation pathways have been extensively studied in vitro and in models of fibrotic diseases, the role of HSC inactivation and its potential value as a pharmacological target have not been explored to the same degree. 
The expression of the characteristic qHSC marker PPAR $\gamma$ is abolished during HSC activation, but the stimulation of PPAR $\gamma$ can halt aHSC proliferation, induce apoptosis, or reverse aHSCs to quiescent-like iHSCs, and it has been shown to ameliorate liver fibrosis in vivo [99,124-126]. HSC-specific PPAR $\gamma$ knockout (Pparg-/-) in mice was shown to not only exacerbate fibrosis development in response to $\mathrm{CCl}_{4}$ but also slow fibrosis regression after the cessation of treatment accompanied by the persistent expression of Col1a1, Acta2, and $\alpha$ SMA, thus indicating continued HSC activation $[27,98]$. The PPAR $\gamma$ agonist rosiglitazone accelerated fibrosis resolution in wildtype mice after the termination of $\mathrm{CCl}_{4}$ administration and coincided with lower levels of Col1a1, Timp1, Acta2, and $\alpha$ SMA, as well as upregulation of Pparg compared to recovering vehicle treated mice [27]. These findings indicated a specific role for PPAR $\gamma$ in HSC inactivation and its importance for fibrosis resolution.

HSCs alter their gene expression profile during activation, which is accompanied by a change in transcription factor expression. Transcription factor 21, involved in fetal HSC differentiation, is decreased in cultured aHSCs and in fibrotic human and murine liver tissue, but it is increased after the discontinuation of $\mathrm{CCl}_{4}$ treatment in mice coinciding with fibrosis regression $[127,128]$. The overexpression of transcription factor 21 was found to upregulate qHSC marker genes (Gfap and $N g f r$ ) and to downregulate profibrotic genes (Pdgfrb, Acta2, and Col1a1) in vitro, and it was found to further reduce Acta2 and Col1a1 expression in mice with $\mathrm{CCl}_{4}$ - or methionine/choline-deficient diet-induced liver fibrosis, accompanied by the regression of fibrosis and steatohepatitis [128]. However, PPAR $\gamma$ expression or lipid droplet uptake were not restored, indicating that complete HSC inactivation was not achieved [128].

Human aHSCs were inactivated in vitro by stimulation with a cocktail containing growth factors, palmitic acid, and retinol, thus leading to the downregulated expression of $\alpha \mathrm{SMA}$ and type 1 collagen, as well as the reduction of proliferation and matrix metalloproteinase activity [129]. ECM organization and retinol metabolism were partly restored to levels exhibited by qHSCs, and 70\% of cells accumulated cytoplasmatic lipid droplets, underlining a switch in phenotype [129]. While most gene expression markers were similar to those of in vivo generated iHSCs, PPAR $\gamma$ expression was not restored in vitro [38,129]. The application of retinol and palmitate alone was also shown to induce HSC inactivation in vitro, as indicated by decreased $\alpha$ SMA and collagen type I expression and an increased lipid droplet storage [130]. However, since saturated free fatty acids like palmitic acid promote NAFLD, the translational potential of this findings remains to be assessed $[47,48]$.

During capillarization, LSECs lose the ability to prevent HSC activation through vascular endothelial growth factor A-stimulated nitric oxide synthesis, but they might actively stimulate HSC activation by secreting proinflammatory cytokines $[29,131,132]$. Conversely, the co-culturing of aHSCs with differentiated LSECs resulted in HSC inactivation, as measured by a reduced expression of $\alpha \mathrm{SMA}$ and collagen type I, as well as the re-establishment of cytosolic fat droplets [29]. The pharmacological stimulation of nitric oxide production in rats with thioacetamide-induced liver cirrhosis restored the differentiated LSEC phenotype, which subsequently led to the apoptosis and inactivation of aHSCs [133]. While studies have shown lower vascular endothelial growth factor A levels in NASH patients compared to healthy controls or to patients with bland steatosis, hepatic angiogenesis driven by vascular endothelial growth factor $\mathrm{A}$ is thought to aid fibrogenesis; therefore, possible interventions targeting LSEC-mediated HSC inactivation should concentrate on downstream effectors [134-136].

Extracellular vesicles can alter the phenotype of their recipient cells and may prove a novel approach to NASH treatment [137]. Accordingly, extracellular vesicles from qHSCs reversed the phenotype of activated HSCs by transferring Ccn2-inhibiting miRNAs, which were diminished in aHSCs in vivo after thioacetic acid or $\mathrm{CCl}_{4}$ treatment [138]. Extracellular vesicles derived from healthy primary murine hepatocytes or AML12 (alpha mouse liver) cells induced the downregulation of Acta2, Ccn2, and Col1a1 expression in aHSCs in vitro [139]. Similarly, serum-derived extracellular vesicles from healthy mice 
suppressed fibrogenesis and decreased aHSC markers in $\mathrm{CCl}_{4}$-treated mice [140]. Likewise, extracellular vesicles from healthy human subjects decreased human hepatic stellate cell line LX-2 activation [140]. This supports extracellular vesicles as important signaling molecules in the reversion of HSC activation and the putative resolution of NASH.

In summary, the above findings reflect the complexity of factors influencing HSC inactivation. One major challenge is the determination and evaluation of the inactivation status, since not all quiescence markers and morphological characteristics may be regained by iHSCs, while some activation markers remain.

Additionally, apoptosis clears aHSCs from the liver, thereby restoring it by removing the primary source of fibrogenic matrix production and increasing matrix resolution, e.g., by reducing aHSC-induced tissue inhibitor of metalloproteinase 1 (TIMP1) expression. Accordingly, aHSC apoptosis has been shown to reverse $\mathrm{CCl}_{4}$-induced hepatic fibrosis in vivo [32]. In pursuing this strategy, several pathways have been suggested as potential targets. This includes the inhibition of NFKB-dependent gene transcription by sulfasalazine, promoting the apoptosis of $\alpha$ SMA-positive stellate cells, and reducing collagen 1 and TIMP1 production, thus leading to the reversion of hepatic fibrosis in vivo [141]. In mice, aHSC apoptosis was achieved by inhibiting C/EBP- $\alpha$ (member of the CCATT/enhancer binding protein family), ultimately promoting the resolution of $\mathrm{CCl}_{4}$-induced hepatic fibrosis [142]. Cultured primary human HSC ( $\alpha$ SMA-positive) showed the expression of TNF-related apoptosis inducing ligand (TRAIL) receptors, with the subsequent blocking of TRAIL-R3 and R4 leading to an increased susceptibility to killing by natural killer cells and suggesting TRAIL-mediated regulation as important in the clearance of aHSCs [143]. However, a limitation in the application of apoptosis-promoting agents is a lack of efficiency in targeting specific cell populations, consequently leading to serious side effects. Cellpenetrating peptides specific for aHSC internalization and subsequent intracellular drug release have been shown to effectively target aHSC in vitro and lead to apoptosis due to cargo-mediated induction [144]. This may prove valuable in the development of novel approaches to fibrosis resolution though aHSC apoptosis.

\section{Pharmacotherapies with Putative Effects on HSCs}

Several of the compounds currently undergoing clinical evaluation may affect fibrosis through HSC activation or/and inactivation (Table 1). With cenicriviroc, the application of CCLR2 and 5 dual antagonists as putative treatment for NASH-associated liver fibrosis, entered phase III clinical trial after showing fibrosis improvement without worsening of NASH in phase II, however the study was recently terminated due to a lack of efficacy (trial id: NCT03028740) [145-147]. Suggested mechanisms include a direct effect on HSC activation by $\mathrm{C}-\mathrm{C}$ chemokine receptor type 5 antagonism and an indirect effect by inhibiting the recruitment of circulating monocytes ( $\mathrm{C}-\mathrm{C}$ chemokine receptor type 2-mediated), as indicated by increased hepatic levels of anti-inflammatory macrophages and decreased pro-inflammatory macrophages in a diet-induced NASH mouse model after cenicriviroc treatment [148]. As detailed above, cellular stress and the ensuing apoptosis contribute to the activation of HSC and the progression of NASH. Apoptosis signal-regulating kinase 1 mediates apoptosis induced by ROS, inflammation, and ER stress, thus constituting an attractive therapeutic target [149]. However, the apoptosis signal-regulating kinase 1 inhibitor selonsertib was not found to improve fibrosis or facilitate NASH resolution in NASH patients with bridging (F3) fibrosis ( $6 \mathrm{mg}, n=321 ; 18 \mathrm{mg}, n=322$ ) or cirrhosis (F4) ( $6 \mathrm{mg}, n=351 ; 18 \mathrm{mg}, n=354$ ) compared to placebo ( $n=159$ and $n=172$, respectively) (NCT03053050 and NCT03053063) [150]. 
Table 1. Clinical trials of pharmacotherapies to improve NASH-associated liver fibrosis.

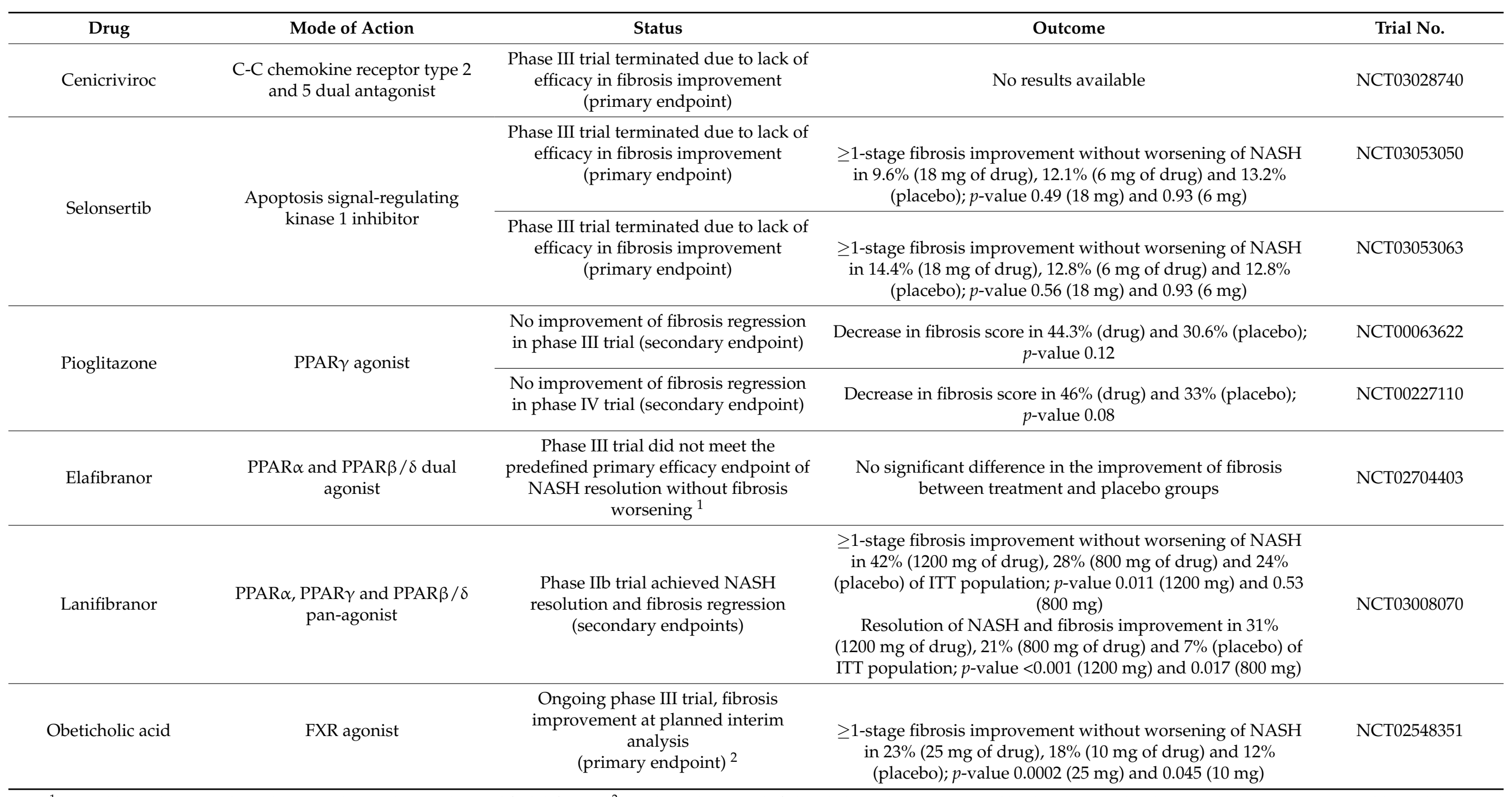

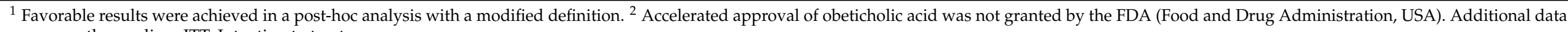
are currently pending. ITT: Intention to treat. 
Though PPARs have been proposed to modulate HSC activation, clinical findings have yet to confirm their effects on NASH-mediated fibrosis. PPAR $\gamma$ agonist pioglitazone showed an improvement of NASH endpoints (steatosis, inflammation, and ballooning hepatocytes) but did not significantly improve fibrosis regression in patients with impaired glucose tolerance/type 2 diabetes ( $45 \mathrm{mg} /$ day, $n=26$ ) or non-diabetic patients with NASH (30 mg/day, $n=70$ ) compared to placebo controls ( $n=21$ and $n=72$, respectively) [151,152]. Moreover, elafibranor, a dual PPAR $\alpha$ and PPAR $\beta / \delta$ agonist, failed to significantly improve NASH and fibrosis in a phase III clinical trial (NCT02704403) [153]. Lanifibranor-a pan-agonist affecting $\operatorname{PPAR} \alpha, \operatorname{PPAR} \gamma$ and $\operatorname{PPAR} \beta / \delta$-is currently showing promising results, achieving NASH resolution and fibrosis regression in a phase IIb clinical trial (NCT03008070) [154].

The FXR agonist obeticholic acid is currently in a phase III clinical trial for NASH treatment (NCT02548351) after two different phase II studies in NAFLD or NASH patients indicated a positive effect on fibrosis (NCT00501592 and NCT01265498) [155,156]. The planned interim analysis confirmed significant improvements in the fibrosis of at least one stage without the worsening of NASH, which was achieved by $23 \%$ of patients with stage F2 or F3 fibrosis treated with $25 \mathrm{mg}$ of obeticholic acid $(n=308)$ compared to $12 \%$ in the placebo group $(n=311)$, but these patients also encountered adverse effects such as pruritus (47 (7\%) in the placebo group, $109(17 \%)$ in the $10 \mathrm{mg}$ of obeticholic acid group, and $115(17 \%)$ in the $25 \mathrm{mg}$ of obeticholic acid group) and elevation of low density lipoprotein $(123(19 \%)$ in the placebo group, $183(28 \%)$ in the $10 \mathrm{mg}$ of obeticholic acid group, and 336 (51\%) in the $25 \mathrm{mg}$ of obeticholic acid group) [157]. Consequently, approval based on these findings was not granted by the FDA (Food and Drug Administration, USA). The included examples of prospective treatment options support effects in NASH, and several showed a beneficial effect on NASH-associated hepatic fibrosis. Collectively, putative effects on HSC activation (either direct or indirectly) remain to be shown.

\section{Conclusions}

In ascertaining a pivotal role in NASH-induced hepatic fibrosis, HSCs and their activation/inactivation represent an interesting therapeutic target. While markers of HSC activation are becoming increasingly known, the inactivated phenotype is less understood. The current incomplete insight into the regulatory mechanisms of the qHSC-aHSC-iHSC interplay in NASH restricts our understanding of the signaling pathways of diseaseassociated fibrosis and concurrent resolution. The further exploration of HSCs and the mechanisms driving the phenotypic switch in NASH is therefore necessary if efforts to identify potential HSC targets for drug development are to succeed.

Author Contributions: Conceptualization, A.Z., D.H.I. and P.T.-N.; writing of the original draft preparation, A.Z.; writing of review and editing, A.Z., D.H.I., and P.T.-N. All authors have read and agreed to the published version of the manuscript.

Funding: Employment of A.Z. is funded by the LifePharm Centre.

Institutional Review Board Statement: Not applicable.

Informed Consent Statement: Not applicable.

Data Availability Statement: No new data were created or analyzed in this study. Data sharing is not applicable to this article.

Conflicts of Interest: D.H.I. is an employee at Novo Nordisk A/S, a company involved in developing new therapies within NASH. A.Z. and P.T.-N. Declare no conflict of interest.

\section{References}

1. Younossi, Z.M.; Koenig, A.B.; Abdelatif, D.; Fazel, Y.; Henry, L.; Wymer, M. Global epidemiology of nonalcoholic fatty liver disease-Meta-analytic assessment of prevalence, incidence, and outcomes. Hepatology 2016, 64, 73-84. [CrossRef] [PubMed]

2. Ibrahim, S.H.; Hirsova, P.; Gores, G.J. Non-alcoholic steatohepatitis pathogenesis: Sublethal hepatocyte injury as a driver of liver inflammation. Gut 2018, 67, 963-972. [CrossRef] [PubMed] 
3. Schwabe, R.F.; Tabas, I.; Pajvani, U.B. Mechanisms of Fibrosis Development in Nonalcoholic Steatohepatitis. Gastroenterology 2020, 158, 1913-1928. [CrossRef]

4. Taylor, R.S.; Taylor, R.J.; Bayliss, S.; Hagström, H.; Nasr, P.; Schattenberg, J.M.; Ishigami, M.; Toyoda, H.; Wai-Sun Wong, V.; Peleg, N.; et al. Association Between Fibrosis Stage and Outcomes of Patients with Nonalcoholic Fatty Liver Disease: A Systematic Review and Meta-Analysis. Gastroenterology 2020, 158, 1611-1625.e1612. [CrossRef] [PubMed]

5. Schuppan, D.; Ashfaq-Khan, M.; Yang, A.T.; Kim, Y.O. Liver fibrosis: Direct antifibrotic agents and targeted therapies. Matrix Biol. 2018, 68-69, 435-451. [CrossRef]

6. Karin, D.; Koyama, Y.; Brenner, D.; Kisseleva, T. The characteristics of activated portal fibroblasts/myofibroblasts in liver fibrosis. Differentiation 2016, 92, 84-92. [CrossRef] [PubMed]

7. Lee, Y.A.; Wallace, M.C.; Friedman, S.L. Pathobiology of liver fibrosis: A translational success story. Gut 2015, 64, 830-841. [CrossRef] [PubMed]

8. Lemoinne, S.; Friedman, S.L. New and emerging anti-fibrotic therapeutics entering or already in clinical trials in chronic liver diseases. Curr. Opin. Pharmacol. 2019, 49, 60-70. [CrossRef]

9. Higashi, T.; Friedman, S.L.; Hoshida, Y. Hepatic stellate cells as key target in liver fibrosis. Adv. Drug Deliv. Rev. 2017, 121, 27-42. [CrossRef] [PubMed]

10. Chalasani, N.; Younossi, Z.; Lavine, J.E.; Diehl, A.M.; Brunt, E.M.; Cusi, K.; Charlton, M.; Sanyal, A.J. The Diagnosis and Management of Non-alcoholic Fatty Liver Disease: Practice Guideline by the American Gastroenterological Association, American Association for the Study of Liver Diseases, and American College of Gastroenterology. Gastroenterology 2012, 142, 1592-1609. [CrossRef]

11. Ipsen, D.H.; Lykkesfeldt, J.; Tveden-Nyborg, P. Molecular mechanisms of hepatic lipid accumulation in non-alcoholic fatty liver disease. Cell Mol. Life Sci. 2018, 75, 3313-3327. [CrossRef] [PubMed]

12. Bedossa, P. Histological Assessment of NAFLD. Dig. Dis. Sci. 2016, 61, 1348-1355. [CrossRef]

13. Ipsen, D.H.; Tveden-Nyborg, P.; Lykkesfeldt, J. Normal weight dyslipidemia: Is it all about the liver? Obes. Silver Spring 2016, 24, 556-567. [CrossRef]

14. Tsuchida, T.; Friedman, S.L. Mechanisms of hepatic stellate cell activation. Nat. Rev. Gastroenterol. Hepatol. 2017, 14, 397-411. [CrossRef] [PubMed]

15. Kleiner, D.E.; Brunt, E.M.; Van Natta, M.; Behling, C.; Contos, M.J.; Cummings, O.W.; Ferrell, L.D.; Liu, Y.C.; Torbenson, M.S.; Unalp-Arida, A.; et al. Design and validation of a histological scoring system for nonalcoholic fatty liver disease. Hepatology 2005, 41, 1313-1321. [CrossRef]

16. Kleiner, D.E.; Makhlouf, H.R. Histology of Nonalcoholic Fatty Liver Disease and Nonalcoholic Steatohepatitis in Adults and Children. Clin. Liver Dis. 2016, 20, 293-312. [CrossRef] [PubMed]

17. Wells, R.G. The portal fibroblast: Not just a poor man's stellate cell. Gastroenterology 2014, 147, 41-47. [CrossRef]

18. Nishio, T.; Hu, R.; Koyama, Y.; Liang, S.; Rosenthal, S.B.; Yamamoto, G.; Karin, D.; Baglieri, J.; Ma, H.Y.; Xu, J.; et al. Activated hepatic stellate cells and portal fibroblasts contribute to cholestatic liver fibrosis in MDR2 knockout mice. J. Hepatol. 2019, 71, 573-585. [CrossRef]

19. Wake, K. "Sternzellen" in the liver: Perisinusoidal cells with special reference to storage of vitamin A. Am. J. Anat. 1971, 132, 429-462. [CrossRef]

20. Blaner, W.S.; O’Byrne, S.M.; Wongsiriroj, N.; Kluwe, J.; D’Ambrosio, D.M.; Jiang, H.; Schwabe, R.F.; Hillman, E.M.; Piantedosi, R.; Libien, J. Hepatic stellate cell lipid droplets: A specialized lipid droplet for retinoid storage. Biochim. Biophys Acta 2009, 1791, 467-473. [CrossRef]

21. Mallat, A.; Lotersztajn, S. Cellular mechanisms of tissue fibrosis. 5. Novel insights into liver fibrosis. Am. J. Physiol. Cell Physiol. 2013, 305, C789-C799. [CrossRef]

22. Geerts, A. History, heterogeneity, developmental biology, and functions of quiescent hepatic stellate cells. Semin. Liver Dis. 2001, 21,311-335. [CrossRef]

23. Wilson, C.L.; Mann, J.; Walsh, M.; Perrugoria, M.J.; Oakley, F.; Wright, M.C.; Brignole, C.; Di Paolo, D.; Perri, P.; Ponzoni, M.; et al. Quiescent hepatic stellate cells functionally contribute to the hepatic innate immune response via TLR3. PLoS ONE 2014, 9, e83391. [CrossRef] [PubMed]

24. De Minicis, S.; Seki, E.; Uchinami, H.; Kluwe, J.; Zhang, Y.; Brenner, D.A.; Schwabe, R.F. Gene expression profiles during hepatic stellate cell activation in culture and in vivo. Gastroenterology 2007, 132, 1937-1946. [CrossRef] [PubMed]

25. Ramachandran, P.; Dobie, R.; Wilson-Kanamori, J.R.; Dora, E.F.; Henderson, B.E.P.; Luu, N.T.; Portman, J.R.; Matchett, K.P.; Brice, M.; Marwick, J.A.; et al. Resolving the fibrotic niche of human liver cirrhosis at single-cell level. Nature 2019, 575, 512-518. [CrossRef] [PubMed]

26. El Taghdouini, A.; Sørensen, A.L.; Reiner, A.H.; Coll, M.; Verhulst, S.; Mannaerts, I.; Øie, C.I.; Smedsrød, B.; Najimi, M.; Sokal, E.; et al. Genome-wide analysis of DNA methylation and gene expression patterns in purified, uncultured human liver cells and activated hepatic stellate cells. Oncotarget 2015, 6, 26729-26745. [CrossRef] [PubMed]

27. Liu, X.; Xu, J.; Rosenthal, S.; Zhang, L.J.; McCubbin, R.; Meshgin, N.; Shang, L.; Koyama, Y.; Ma, H.Y.; Sharma, S.; et al. Identification of Lineage-Specific Transcription Factors That Prevent Activation of Hepatic Stellate Cells and Promote Fibrosis Resolution. Gastroenterology 2020, 158, 1728.e1714-1744.e1714. [CrossRef] [PubMed] 
28. Chu, A.L.; Schilling, J.D.; King, K.R.; Feldstein, A.E. The Power of Single Cell Analysis for the Study of Liver Pathobiology. Hepatology 2020, 73, 437-448. [CrossRef]

29. Deleve, L.D.; Wang, X.; Guo, Y. Sinusoidal endothelial cells prevent rat stellate cell activation and promote reversion to quiescence. Hepatology 2008, 48, 920-930. [CrossRef]

30. Martinez-Hernandez, A.; Martinez, J. The role of capillarization in hepatic failure: Studies in carbon tetrachloride-induced cirrhosis. Hepatology 1991, 14, 864-874. [CrossRef]

31. Schuppan, D.; Ruehl, M.; Somasundaram, R.; Hahn, E.G. Matrix as a modulator of hepatic fibrogenesis. Semin. Liver Dis. 2001, 21, 351-372. [CrossRef]

32. Iredale, J.P.; Benyon, R.C.; Pickering, J.; McCullen, M.; Northrop, M.; Pawley, S.; Hovell, C.; Arthur, M.J.P. Mechanisms of spontaneous resolution of rat liver fibrosis-Hepatic stellate cell apoptosis and reduced hepatic expression of metalloproteinase inhibitors. J. Clin. Invest. 1998, 102, 538-549. [CrossRef]

33. Dobie, R.; Wilson-Kanamori, J.R.; Henderson, B.E.P.; Smith, J.R.; Matchett, K.P.; Portman, J.R.; Wallenborg, K.; Picelli, S.; Zagorska, A.; Pendem, S.V.; et al. Single-Cell Transcriptomics Uncovers Zonation of Function in the Mesenchyme during Liver Fibrosis. Cell Rep. 2019, 29, 1832-1847.e1838. [CrossRef]

34. Lu, W.Y.; Bird, T.G.; Boulter, L.; Tsuchiya, A.; Cole, A.M.; Hay, T.; Guest, R.V.; Wojtacha, D.; Man, T.Y.; Mackinnon, A.; et al. Hepatic progenitor cells of biliary origin with liver repopulation capacity. Nat. Cell Biol. 2015, 17, 971-983. [CrossRef]

35. Gadd, V.L.; Skoien, R.; Powell, E.E.; Fagan, K.J.; Winterford, C.; Horsfall, L.; Irvine, K.; Clouston, A.D. The portal inflammatory infiltrate and ductular reaction in human nonalcoholic fatty liver disease. Hepatology 2014, 59, 1393-1405. [CrossRef]

36. Wu, N.; Meng, F.; Invernizzi, P.; Bernuzzi, F.; Venter, J.; Standeford, H.; Onori, P.; Marzioni, M.; Alvaro, D.; Franchitto, A.; et al. The secretin/secretin receptor axis modulates liver fibrosis through changes in transforming growth factor- $\beta 1$ biliary secretion in mice. Hepatology 2016, 64, 865-879. [CrossRef]

37. Iredale, J.P. Hepatic stellate cell behavior during resolution of liver injury. Semin. Liver Dis 2001, 21, 427-436. [CrossRef]

38. Kisseleva, T.; Cong, M.; Paik, Y.; Scholten, D.; Jiang, C.Y.; Benner, C.; Iwaisako, K.; Moore-Morris, T.; Scott, B.; Tsukamoto, H.; et al. Myofibroblasts revert to an inactive phenotype during regression of liver fibrosis. Proc. Natl. Acad. Sci. USA 2012, 109, 9448-9453. [CrossRef] [PubMed]

39. Troeger, J.S.; Mederacke, I.; Gwak, G.Y.; Dapito, D.H.; Mu, X.; Hsu, C.C.; Pradere, J.P.; Friedman, R.A.; Schwabe, R.F. Deactivation of hepatic stellate cells during liver fibrosis resolution in mice. Gastroenterology 2012, 143, 1073-1083 e1022. [CrossRef] [PubMed]

40. Teratani, T.; Tomita, K.; Suzuki, T.; Oshikawa, T.; Yokoyama, H.; Shimamura, K.; Tominaga, S.; Hiroi, S.; Irie, R.; Okada, Y.; et al. A high-cholesterol diet exacerbates liver fibrosis in mice via accumulation of free cholesterol in hepatic stellate cells. Gastroenterology 2012, 142, 152-164 e110. [CrossRef] [PubMed]

41. Musso, G.; Gambino, R.; Cassader, M. Cholesterol metabolism and the pathogenesis of non-alcoholic steatohepatitis. Prog. Lipid Res. 2013, 52, 175-191. [CrossRef] [PubMed]

42. Pradere, J.P.; Kluwe, J.; De Minicis, S.; Jiao, J.J.; Gwak, G.Y.; Dapito, D.H.; Jang, M.K.; Guenther, N.D.; Mederacke, I.; Friedman, R.; et al. Hepatic macrophages but not dendritic cells contribute to liver fibrosis by promoting the survival of activated hepatic stellate cells in mice. Hepatology 2013, 58, 1461-1473. [CrossRef] [PubMed]

43. Shimamura, T.; Fujisawa, T.; Husain, S.R.; Kioi, M.; Nakajima, A.; Puri, R.K. Novel role of IL-13 in fibrosis induced by nonalcoholic steatohepatitis and its amelioration by IL-13R-directed cytotoxin in a rat model. J. Immunol. 2008, 181, 4656-4665. [CrossRef] [PubMed]

44. Liu, Y.; Meyer, C.; Muller, A.; Herweck, F.; Li, Q.; Mullenbach, R.; Mertens, P.R.; Dooley, S.; Weng, H.L. IL-13 induces connective tissue growth factor in rat hepatic stellate cells via TGF-beta-independent Smad signaling. J. Immunol. 2011, 187, 2814-2823. [CrossRef] [PubMed]

45. Heinrichs, D.; Berres, M.L.; Nellen, A.; Fischer, P.; Scholten, D.; Trautwein, C.; Wasmuth, H.E.; Sahin, H. The chemokine CCL3 promotes experimental liver fibrosis in mice. PLoS ONE 2013, 8, e66106. [CrossRef] [PubMed]

46. Berres, M.L.; Koenen, R.R.; Rueland, A.; Zaldivar, M.M.; Heinrichs, D.; Sahin, H.; Schmitz, P.; Streetz, K.L.; Berg, T.; Gassler, N.; et al. Antagonism of the chemokine Ccl5 ameliorates experimental liver fibrosis in mice. J. Clin. Invest 2010, 120, 4129-4140. [CrossRef] [PubMed]

47. Seki, E.; Schwabe, R.F. Hepatic inflammation and fibrosis: Functional links and key pathways. Hepatology 2015, 61, 1066-1079. [CrossRef]

48. Schnabl, B.; Brenner, D.A. Interactions between the intestinal microbiome and liver diseases. Gastroenterology 2014, 146, 1513-1524. [CrossRef]

49. Zhang, J.; Zhao, Y.; Xu, C.; Hong, Y.; Lu, H.; Wu, J.; Chen, Y. Association between serum free fatty acid levels and nonalcoholic fatty liver disease: A cross-sectional study. Sci. Rep. 2014, 4, 5832. [CrossRef]

50. Tarantino, G.; Conca, P.; Riccio, A.; Tarantino, M.; Di Minno, M.N.; Chianese, D.; Pasanisi, F.; Contaldo, F.; Scopacasa, F.; Capone, D. Enhanced serum concentrations of transforming growth factor-beta1 in simple fatty liver: Is it really benign? J. Transl. Med. 2008, 6, 72. [CrossRef]

51. Sepulveda-Flores, R.N.; Vera-Cabrera, L.; Flores-Gutierrez, J.P.; Maldonado-Garza, H.; Salinas-Garza, R.; Zorrilla-Blanco, P.; Bosques-Padilla, F.J. Obesity-related non-alcoholic steatohepatitis and TGF-beta1 serum levels in relation to morbid obesity. Ann. Hepatol. 2002, 1, 36-39. [CrossRef] 
52. Nair, B.; Nath, L.R. Inevitable role of TGF- $\beta 1$ in progression of nonalcoholic fatty liver disease. J. Recept Signal Transduct. Res. 2020, 40, 195-200. [CrossRef]

53. Richter, K.; Konzack, A.; Pihlajaniemi, T.; Heljasvaara, R.; Kietzmann, T. Redox-fibrosis: Impact of TGF $\beta 1$ on ROS generators, mediators and functional consequences. Redox Biol. 2015, 6, 344-352. [CrossRef]

54. Dooley, S.; ten Dijke, P. TGF-beta in progression of liver disease. Cell Tissue Res. 2012, 347, 245-256. [CrossRef]

55. Nieto, N.; Dominguez-Rosales, J.A.; Fontana, L.; Salazar, A.; Armendariz-Borunda, J.; Greenwel, P.; Rojkind, M. Rat hepatic stellate cells contribute to the acute-phase response with increased expression of alpha1(I) and alpha1(IV) collagens, tissue inhibitor of metalloproteinase-1, and matrix-metalloproteinase-2 messenger RNAs. Hepatology 2001, 33, 597-607. [CrossRef] [PubMed]

56. Inagaki, Y.; Truter, S.; Greenwel, P.; Rojkind, M.; Unoura, M.; Kobayashi, K.; Ramirez, F. Regulation of the alpha 2(I) collagen gene transcription in fat-storing cells derived from a cirrhotic liver. Hepatology 1995, 22, 573-579.

57. Herbst, H.; Wege, T.; Milani, S.; Pellegrini, G.; Orzechowski, H.D.; Bechstein, W.O.; Neuhaus, P.; Gressner, A.M.; Schuppan, D. Tissue inhibitor of metalloproteinase-1 and -2 RNA expression in rat and human liver fibrosis. Am. J. Pathol. 1997, 150, 1647-1659. [PubMed]

58. Furukawa, F.; Matsuzaki, K.; Mori, S.; Tahashi, Y.; Yoshida, K.; Sugano, Y.; Yafnagata, H.; Matsushita, M.; Seki, T.; Inagaki, Y.; et al. p38 MAPK mediates fibrogenic signal through Smad3 phosphorylation in rat myofibroblasts. Hepatology 2003, 38, 879-889. [CrossRef] [PubMed]

59. Yoshida, K.; Matsuzaki, K.; Mori, S.; Tahashi, Y.; Yamagata, H.; Furukawa, F.; Seki, T.; Nishizawa, M.; Fujisawa, J.; Okazaki, K. Transforming growth factor-beta and platelet-derived growth factor signal via c-Jun N-terminal kinase-dependent Smad2/3 phosphorylation in rat hepatic stellate cells after acute liver injury. Am. J. Pathol. 2005, 166, 1029-1039. [CrossRef]

60. Dooley, S.; Delvoux, B.; Lahme, B.; Mangasser-Stephan, K.; Gressner, A.M. Modulation of transforming growth factor beta response and signaling during transdifferentiation of rat hepatic stellate cells to myofibroblasts. Hepatology 2000, 31, 1094-1106. [CrossRef]

61. Tahashi, Y.; Matsuzaki, K.; Date, M.; Yoshida, K.; Furukawa, F.; Sugano, Y.; Matsushita, M.; Himeno, Y.; Inagaki, Y.; Inoue, K. Differential regulation of TGF-beta signal in hepatic stellate cells between acute and chronic rat liver injury. Hepatology 2002, 35, 49-61. [CrossRef] [PubMed]

62. Lee, S.J.; Kang, J.H.; Choi, S.Y.; Suk, K.T.; Kim, D.J.; Kwon, O.S. PKCdelta as a regulator for TGFbeta1-induced alpha-SMA production in a murine nonalcoholic steatohepatitis model. PLoS ONE 2013, 8, e55979. [CrossRef]

63. Wipff, P.J.; Rifkin, D.B.; Meister, J.J.; Hinz, B. Myofibroblast contraction activates latent TGF-beta1 from the extracellular matrix. J. Cell Biol. 2007, 179, 1311-1323. [CrossRef] [PubMed]

64. Martin, K.; Pritchett, J.; Llewellyn, J.; Mullan, A.F.; Athwal, V.S.; Dobie, R.; Harvey, E.; Zeef, L.; Farrow, S.; Streuli, C.; et al. PAK proteins and YAP-1 signalling downstream of integrin beta-1 in myofibroblasts promote liver fibrosis. Nat. Commun. 2016, 7, 12502. [CrossRef] [PubMed]

65. Henderson, N.C.; Arnold, T.D.; Katamura, Y.; Giacomini, M.M.; Rodriguez, J.D.; McCarty, J.H.; Pellicoro, A.; Raschperger, E.; Betsholtz, C.; Ruminski, P.G.; et al. Targeting of alphav integrin identifies a core molecular pathway that regulates fibrosis in several organs. Nat. Med. 2013, 19, 1617-1624. [CrossRef]

66. Mannaerts, I.; Leite, S.B.; Verhulst, S.; Claerhout, S.; Eysackers, N.; Thoen, L.F.; Hoorens, A.; Reynaert, H.; Halder, G.; van Grunsven, L.A. The Hippo pathway effector YAP controls mouse hepatic stellate cell activation. J. Hepatol. 2015, 63, 679-688. [CrossRef] [PubMed]

67. Paradis, V.; Perlemuter, G.; Bonvoust, F.; Dargere, D.; Parfait, B.; Vidaud, M.; Conti, M.; Huet, S.; Ba, N.; Buffet, C.; et al. High glucose and hyperinsulinemia stimulate connective tissue growth factor expression: A potential mechanism involved in progression to fibrosis in nonalcoholic steatohepatitis. Hepatology 2001, 34, 738-744. [CrossRef]

68. Walter, R.; Wanninger, J.; Bauer, S.; Eisinger, K.; Neumeier, M.; Weiss, T.S.; Amann, T.; Hellerbrand, C.; Schaffler, A.; Scholmerich, J.; et al. Adiponectin reduces connective tissue growth factor in human hepatocytes which is already induced in non-fibrotic non-alcoholic steatohepatitis. Exp. Mol. Pathol. 2011, 91, 740-744. [CrossRef]

69. Colak, Y.; Senates, E.; Coskunpinar, E.; Oltulu, Y.M.; Zemheri, E.; Ozturk, O.; Doganay, L.; Mesci, B.; Yilmaz, Y.; Enc, F.Y.; et al. Concentrations of connective tissue growth factor in patients with nonalcoholic fatty liver disease: Association with liver fibrosis. Dis. Markers 2012, 33, 77-83. [CrossRef]

70. Sakai, K.; Jawaid, S.; Sasaki, T.; Bou-Gharios, G.; Sakai, T. Transforming growth factor-beta-independent role of connective tissue growth factor in the development of liver fibrosis. Am. J. Pathol. 2014, 184, 2611-2617. [CrossRef]

71. Huang, G.; Brigstock, D.R. Regulation of hepatic stellate cells by connective tissue growth factor. Front Biosci. (Landmark Ed.) 2012, 17, 2495-2507. [CrossRef]

72. Hao, C.; Xie, Y.; Peng, M.; Ma, L.; Zhou, Y.; Zhang, Y.; Kang, W.; Wang, J.; Bai, X.; Wang, P.; et al. Inhibition of connective tissue growth factor suppresses hepatic stellate cell activation in vitro and prevents liver fibrosis in vivo. Clin. Exp. Med. 2014, 14, 141-150. [CrossRef]

73. Bonner, J.C. Regulation of PDGF and its receptors in fibrotic diseases. Cytokine Growth Factor Rev. 2004, 15, 255-273. [CrossRef] [PubMed]

74. Czochra, P.; Klopcic, B.; Meyer, E.; Herkel, J.; Garcia-Lazaro, J.F.; Thieringer, F.; Schirmacher, P.; Biesterfeld, S.; Galle, P.R.; Lohse, A.W.; et al. Liver fibrosis induced by hepatic overexpression of PDGF-B in transgenic mice. J. Hepatol. 2006, 45, 419-428. [CrossRef] 
75. Moylan, C.A.; Pang, H.; Dellinger, A.; Suzuki, A.; Garrett, M.E.; Guy, C.D.; Murphy, S.K.; Ashley-Koch, A.E.; Choi, S.S.; Michelotti, G.A.; et al. Hepatic gene expression profiles differentiate presymptomatic patients with mild versus severe nonalcoholic fatty liver disease. Hepatology 2014, 59, 471-482. [CrossRef]

76. Lambrecht, J.; Verhulst, S.; Mannaerts, I.; Sowa, J.-P.; Best, J.; Canbay, A.; Reynaert, H.; van Grunsven, L.A. A PDGFR $\beta$-based score predicts significant liver fibrosis in patients with chronic alcohol abuse, NAFLD and viral liver disease. EBioMedicine 2019, 43, 501-512. [CrossRef]

77. Wong, L.; Yamasaki, G.; Johnson, R.J.; Friedman, S.L. Induction of beta-platelet-derived growth factor receptor in rat hepatic lipocytes during cellular activation in vivo and in culture. J. Clin. Invest. 1994, 94, 1563-1569. [CrossRef]

78. Kocabayoglu, P.; Lade, A.; Lee, Y.A.; Dragomir, A.-C.; Sun, X.; Fiel, M.I.; Thung, S.; Aloman, C.; Soriano, P.; Hoshida, Y.; et al. $\beta$-PDGF receptor expressed by hepatic stellate cells regulates fibrosis in murine liver injury, but not carcinogenesis. J. Hepatol. 2015, 63, 141-147. [CrossRef] [PubMed]

79. Yang, L.; Wang, Y.; Mao, H.; Fleig, S.; Omenetti, A.; Brown, K.D.; Sicklick, J.K.; Li, Y.X.; Diehl, A.M. Sonic hedgehog is an autocrine viability factor for myofibroblastic hepatic stellate cells. J. Hepatol. 2008, 48, 98-106. [CrossRef] [PubMed]

80. Jung, Y.; Brown, K.D.; Witek, R.P.; Omenetti, A.; Yang, L.; Vandongen, M.; Milton, R.J.; Hines, I.N.; Rippe, R.A.; Spahr, L.; et al. Accumulation of hedgehog-responsive progenitors parallels alcoholic liver disease severity in mice and humans. Gastroenterology 2008, 134, 1532-1543. [CrossRef]

81. Machado, M.V.; Michelotti, G.A.; Pereira Tde, A.; Boursier, J.; Kruger, L.; Swiderska-Syn, M.; Karaca, G.; Xie, G.; Guy, C.D.; Bohinc, B.; et al. Reduced lipoapoptosis, hedgehog pathway activation and fibrosis in caspase-2 deficient mice with non-alcoholic steatohepatitis. Gut 2015, 64, 1148-1157. [CrossRef]

82. Omenetti, A.; Choi, S.; Michelotti, G.; Diehl, A.M. Hedgehog signaling in the liver. J. Hepatol. 2011, 54, 366-373. [CrossRef]

83. Sicklick, J.K.; Li, Y.X.; Choi, S.S.; Qi, Y.; Chen, W.; Bustamante, M.; Huang, J.; Zdanowicz, M.; Camp, T.; Torbenson, M.S.; et al. Role for hedgehog signaling in hepatic stellate cell activation and viability. Lab. Invest. 2005, 85, 1368-1380. [CrossRef]

84. Omenetti, A.; Yang, L.; Li, Y.X.; McCall, S.J.; Jung, Y.; Sicklick, J.K.; Huang, J.; Choi, S.; Suzuki, A.; Diehl, A.M. Hedgehog-mediated mesenchymal-epithelial interactions modulate hepatic response to bile duct ligation. Lab. Invest. 2007, 87, 499-514. [CrossRef] [PubMed]

85. Syn, W.K.; Jung, Y.; Omenetti, A.; Abdelmalek, M.; Guy, C.D.; Yang, L.; Wang, J.; Witek, R.P.; Fearing, C.M.; Pereira, T.A.; et al. Hedgehog-mediated epithelial-to-mesenchymal transition and fibrogenic repair in nonalcoholic fatty liver disease. Gastroenterology 2009, 137, 1478-1488 e1478. [CrossRef] [PubMed]

86. Guy, C.D.; Suzuki, A.; Zdanowicz, M.; Abdelmalek, M.F.; Burchette, J.; Unalp, A.; Diehl, A.M.; Crn, N. Hedgehog pathway activation parallels histologic severity of injury and fibrosis in human nonalcoholic fatty liver disease. Hepatology 2012, 55, 1711-1721. [CrossRef] [PubMed]

87. Michelotti, G.A.; Xie, G.; Swiderska, M.; Choi, S.S.; Karaca, G.; Kruger, L.; Premont, R.; Yang, L.; Syn, W.K.; Metzger, D.; et al. Smoothened is a master regulator of adult liver repair. J. Clin. Invest. 2013, 123, 2380-2394. [CrossRef] [PubMed]

88. Hirsova, P.; Ibrahim, S.H.; Bronk, S.F.; Yagita, H.; Gores, G.J. Vismodegib suppresses TRAIL-mediated liver injury in a mouse model of nonalcoholic steatohepatitis. PLoS ONE 2013, 8, e70599. [CrossRef] [PubMed]

89. Chen, Y.; Choi, S.S.; Michelotti, G.A.; Chan, I.S.; Swiderska-Syn, M.; Karaca, G.F.; Xie, G.; Moylan, C.A.; Garibaldi, F.; Premont, R.; et al. Hedgehog controls hepatic stellate cell fate by regulating metabolism. Gastroenterology 2012, 143, 1319-1329.e1311. [CrossRef] [PubMed]

90. van Grunsven, L.A. 3D in vitro models of liver fibrosis. Adv. Drug. Deliv. Rev. 2017, 121, 133-146. [CrossRef]

91. Fisher, C.D.; Lickteig, A.J.; Augustine, L.M.; Ranger-Moore, J.; Jackson, J.P.; Ferguson, S.S.; Cherrington, N.J. Hepatic cytochrome P450 enzyme alterations in humans with progressive stages of nonalcoholic fatty liver disease. Drug Metab. Dispos. 2009, 37, 2087-2094. [CrossRef]

92. Han, J.; He, Y.P.; Zhao, H.; Xu, X.W. Hypoxia inducible factor-1 promotes liver fibrosis in nonalcoholic fatty liver disease by activating PTEN/p65 signaling pathway. J. Cell Biochem. 2019, 120, 14735-14744. [CrossRef] [PubMed]

93. Cave, M.C.; Clair, H.B.; Hardesty, J.E.; Falkner, K.C.; Feng, W.; Clark, B.J.; Sidey, J.; Shi, H.; Aqel, B.A.; McClain, C.J.; et al. Nuclear receptors and nonalcoholic fatty liver disease. Biochim. Biophys. Acta 2016, 1859, 1083-1099. [CrossRef] [PubMed]

94. Fuchs, C.D.; Traussnigg, S.A.; Trauner, M. Nuclear Receptor Modulation for the Treatment of Nonalcoholic Fatty Liver Disease. Semin. Liver Dis. 2016, 36, 69-86. [CrossRef] [PubMed]

95. She, H.; Xiong, S.; Hazra, S.; Tsukamoto, H. Adipogenic transcriptional regulation of hepatic stellate cells. J. Biol. Chem. 2005, 280, 4959-4967. [CrossRef]

96. Yan, K.; Deng, X.; Zhai, X.; Zhou, M.; Jia, X.; Luo, L.; Niu, M.; Zhu, H.; Qiang, H.; Zhou, Y. p38 mitogen-activated protein kinase and liver $X$ receptor-alpha mediate the leptin effect on sterol regulatory element binding protein-1c expression in hepatic stellate cells. Mol. Med. 2012, 18, 10-18. [CrossRef]

97. Beaven, S.W.; Wroblewski, K.; Wang, J.H.; Hong, C.; Bensinger, S.; Tsukamoto, H.; Tontonoz, P. Liver X Receptor Signaling Is a Determinant of Stellate Cell Activation and Susceptibility to Fibrotic Liver Disease. Gastroenterology 2011, 140, 1052-1062. [CrossRef]

98. Moran-Salvador, E.; Titos, E.; Rius, B.; Gonzalez-Periz, A.; Garcia-Alonso, V.; Lopez-Vicario, C.; Miquel, R.; Barak, Y.; Arroyo, V.; Claria, J. Cell-specific PPARgamma deficiency establishes anti-inflammatory and anti-fibrogenic properties for this nuclear receptor in non-parenchymal liver cells. J. Hepatol. 2013, 59, 1045-1053. [CrossRef] 
99. Nan, Y.M.; Han, F.; Kong, L.B.; Zhao, S.X.; Wang, R.Q.; Wu, W.J.; Yu, J. Adenovirus-mediated peroxisome proliferator activated receptor gamma overexpression prevents nutritional fibrotic steatohepatitis in mice. Scand. J. Gastroenterol. 2011, 46, 358-369. [CrossRef]

100. Yao, J.; Zhou, C.S.; Ma, X.; Fu, B.Q.; Tao, L.S.; Chen, M.; Xu, Y.P. FXR agonist GW4064 alleviates endotoxin-induced hepatic inflammation by repressing macrophage activation. World J. Gastroenterol. 2014, 20, 14430-14441. [CrossRef]

101. Fiorucci, S.; Rizzo, G.; Antonelli, E.; Renga, B.; Mencarelli, A.; Riccardi, L.; Morelli, A.; Pruzanski, M.; Pellicciari, R. Cross-talk between farnesoid-X-receptor (FXR) and peroxisome proliferator-activated receptor $\gamma$ contributes to the antifibrotic activity of FXR ligands in rodent models of liver cirrhosis. J. Pharmacol. Exp. Ther. 2005, 315, 58-68. [CrossRef]

102. Fiorucci, S.; Rizzo, G.; Antonelli, E.; Renga, B.; Mencarelli, A.; Riccardi, L.; Orlandi, S.; Pruzanski, M.; Morelli, A.; Pellicciari, R. A farnesoid $x$ receptor-small heterodimer partner regulatory cascade modulates tissue metalloproteinase inhibitor- 1 and matrix metalloprotease expression in hepatic stellate cells and promotes resolution of liver fibrosis. J. Pharmacol. Exp. Ther. 2005, 314, 584-595. [CrossRef]

103. Zhang, S.; Wang, J.; Liu, Q.; Harnish, D.C. Farnesoid X receptor agonist WAY-362450 attenuates liver inflammation and fibrosis in murine model of non-alcoholic steatohepatitis. J. Hepatol. 2009, 51, 380-388. [CrossRef]

104. Kong, B.; Luyendyk, J.P.; Tawfik, O.; Guo, G.L. Farnesoid X Receptor Deficiency Induces Nonalcoholic Steatohepatitis in Low-Density Lipoprotein Receptor-Knockout Mice Fed a High-Fat Diet. J. Pharmacol. Exp. Ther. 2009, 328, 116-122. [CrossRef]

105. Jung, D.; Mangelsdorf, D.J.; Meyer, U.A. Pregnane X receptor is a target of farnesoid X receptor. J. Biol. Chem. 2006, 281, 19081-19091. [CrossRef]

106. Sookoian, S.; Castano, G.O.; Burgueno, A.L.; Gianotti, T.F.; Rosselli, M.S.; Pirola, C.J. The nuclear receptor PXR gene variants are associated with liver injury in nonalcoholic fatty liver disease. Pharm. Genom. 2010, 20, 1-8. [CrossRef]

107. Haughton, E.L.; Tucker, S.J.; Marek, C.J.; Durward, E.; Leel, V.; Bascal, Z.; Monaghan, T.; Koruth, M.; Collie-Duguid, E.; Mann, D.A.; et al. Pregnane $X$ receptor activators inhibit human hepatic stellate cell transdifferentiation in vitro. Gastroenterology 2006, 131, 194-209. [CrossRef]

108. Marek, C.J.; Tucker, S.J.; Konstantinou, D.K.; Elrick, L.J.; Haefner, D.; Sigalas, C.; Murray, G.I.; Goodwin, B.; Wright, M.C. Pregnenolone-16alpha-carbonitrile inhibits rodent liver fibrogenesis via PXR (pregnane X receptor)-dependent and PXRindependent mechanisms. Biochem. J. 2005, 387, 601-608. [CrossRef] [PubMed]

109. Yang, N.; Shi, J.J.; Wu, F.P.; Li, M.; Zhang, X.; Li, Y.P.; Zhai, S.; Jia, X.L.; Dang, S.S. Caffeic acid phenethyl ester up-regulates antioxidant levels in hepatic stellate cell line T6 via an Nrf2-mediated mitogen activated protein kinases pathway. World J. Gastroenterol. 2017, 23, 1203-1214. [CrossRef] [PubMed]

110. Yang, J.H.; Kim, K.M.; Cho, S.S.; Shin, S.M.; Ka, S.O.; Na, C.S.; Park, B.H.; Jegal, K.H.; Kim, J.K.; Ku, S.K.; et al. Inhibitory Effect of Sestrin 2 on Hepatic Stellate Cell Activation and Liver Fibrosis. Antioxid. Redox. Signal. 2019, 31, 243-259. [CrossRef] [PubMed]

111. Fayez, A.M.; Zakaria, S.; Moustafa, D. Alpha lipoic acid exerts antioxidant effect via Nrf2/HO-1 pathway activation and suppresses hepatic stellate cells activation induced by methotrexate in rats. Biomed. Pharmacother. 2018, 105, 428-433. [CrossRef] [PubMed]

112. Tang, Y. Curcumin targets multiple pathways to halt hepatic stellate cell activation: Updated mechanisms in vitro and in vivo. Dig. Dis. Sci. 2015, 60, 1554-1564. [CrossRef] [PubMed]

113. Hernández-Gea, V.; Hilscher, M.; Rozenfeld, R.; Lim, M.P.; Nieto, N.; Werner, S.; Devi, L.A.; Friedman, S.L. Endoplasmic reticulum stress induces fibrogenic activity in hepatic stellate cells through autophagy. J. Hepatol. 2013, 59, 98-104. [CrossRef] [PubMed]

114. Lee, S.; Kim, S.; Hwang, S.; Cherrington, N.J.; Ryu, D.Y. Dysregulated expression of proteins associated with ER stress, autophagy and apoptosis in tissues from nonalcoholic fatty liver disease. Oncotarget 2017, 8, 63370-63381. [CrossRef] [PubMed]

115. Hernández-Gea, V.; Ghiassi-Nejad, Z.; Rozenfeld, R.; Gordon, R.; Fiel, M.I.; Yue, Z.; Czaja, M.J.; Friedman, S.L. Autophagy Releases Lipid That Promotes Fibrogenesis by Activated Hepatic Stellate Cells in Mice and in Human Tissues. Gastroenterology 2012, 142, 938-946. [CrossRef] [PubMed]

116. Thoen, L.F.; Guimaraes, E.L.; Dolle, L.; Mannaerts, I.; Najimi, M.; Sokal, E.; van Grunsven, L.A. A role for autophagy during hepatic stellate cell activation. J. Hepatol. 2011, 55, 1353-1360. [CrossRef]

117. Shirakami, Y.; Lee, S.A.; Clugston, R.D.; Blaner, W.S. Hepatic metabolism of retinoids and disease associations. Biochim. Biophys. Acta 2012, 1821, 124-136. [CrossRef]

118. Jophlin, L.L.; Koutalos, Y.; Chen, C.; Shah, V.; Rockey, D.C. Hepatic stellate cells retain retinoid-laden lipid droplets after cellular transdifferentiation into activated myofibroblasts. Am. J. Physiol. Gastrointest. Liver Physiol. 2018, 315, G713-G721. [CrossRef]

119. Kluwe, J.; Wongsiriroj, N.; Troeger, J.S.; Gwak, G.Y.; Dapito, D.H.; Pradere, J.P.; Jiang, H.; Siddiqi, M.; Piantedosi, R.; O’Byrne, S.M.; et al. Absence of hepatic stellate cell retinoid lipid droplets does not enhance hepatic fibrosis but decreases hepatic carcinogenesis. Gut 2011, 60, 1260-1268. [CrossRef]

120. Ye, Y.; Dan, Z. All-trans retinoic acid diminishes collagen production in a hepatic stellate cell line via suppression of active protein-1 and c-Jun N-terminal kinase signal. J. Huazhong Univ. Sci. Technolog. Med. Sci. 2010, 30, 726-733. [CrossRef]

121. Senoo, H.; Wake, K. Suppression of experimental hepatic fibrosis by administration of vitamin A. Lab. Invest. 1985, 52, 182-194.

122. Hisamori, S.; Tabata, C.; Kadokawa, Y.; Okoshi, K.; Tabata, R.; Mori, A.; Nagayama, S.; Watanabe, G.; Kubo, H.; Sakai, Y. All-trans-retinoic acid ameliorates carbon tetrachloride-induced liver fibrosis in mice through modulating cytokine production. Liver Int. 2008, 28, 1217-1225. [CrossRef] 
123. De Minicis, S.; Candelaresi, C.; Agostinelli, L.; Taffetani, S.; Saccomanno, S.; Rychlicki, C.; Trozzi, L.; Marzioni, M.; Benedetti, A.; Svegliati-Baroni, G. Endoplasmic Reticulum stress induces hepatic stellate cell apoptosis and contributes to fibrosis resolution. Liver Int. 2012, 32, 1574-1584. [CrossRef] [PubMed]

124. Miyahara, T.; Schrum, L.; Rippe, R.; Xiong, S.G.; Yee, H.F.; Motomura, K.; Anania, F.A.; Willson, T.M.; Tsukamoto, H. Peroxisome proliferator-activated receptors and hepatic stellate cell activation. J. Biol. Chem. 2000, 275, 35715-35722. [CrossRef] [PubMed]

125. Sun, K.; Wang, Q.; Huang, X.H. PPAR gamma inhibits growth of rat hepatic stellate cells and TGF beta-induced connective tissue growth factor expression. Acta Pharmacol. Sin. 2006, 27, 715-723. [CrossRef] [PubMed]

126. Yang, L.; Chan, C.C.; Kwon, O.S.; Liu, S.; McGhee, J.; Stimpson, S.A.; Chen, L.Z.; Harrington, W.W.; Symonds, W.T.; Rockey, D.C. Regulation of peroxisome proliferator-activated receptor-gamma in liver fibrosis. Am. J. Physiol. Gastrointest. Liver Physiol. 2006, 291, G902-G911. [CrossRef]

127. Acharya, A.; Baek, S.T.; Huang, G.; Eskiocak, B.; Goetsch, S.; Sung, C.Y.; Banfi, S.; Sauer, M.F.; Olsen, G.S.; Duffield, J.S.; et al. The bHLH transcription factor Tcf21 is required for lineage-specific EMT of cardiac fibroblast progenitors. Development 2012, 139, 2139-2149. [CrossRef] [PubMed]

128. Nakano, Y.; Kamiya, A.; Sumiyoshi, H.; Tsuruya, K.; Kagawa, T.; Inagaki, Y. A Deactivation Factor of Fibrogenic Hepatic Stellate Cells Induces Regression of Liver Fibrosis in Mice. Hepatology 2020, 71, 1437-1452. [CrossRef] [PubMed]

129. El Taghdouini, A.; Najimi, M.; Sancho-Bru, P.; Sokal, E.; van Grunsven, L.A. In vitro reversion of activated primary human hepatic stellate cells. Fibrogenesis Tissue Repair 2015, 8, 14. [CrossRef]

130. Lee, T.F.; Mak, K.M.; Rackovsky, O.; Lin, Y.L.; Kwong, A.J.; Loke, J.C.; Friedman, S.L. Downregulation of hepatic stellate cell activation by retinol and palmitate mediated by adipose differentiation-related protein (ADRP). J. Cell Physiol. 2010, 223, 648-657. [CrossRef]

131. Jarnagin, W.R.; Rockey, D.C.; Koteliansky, V.E.; Wang, S.S.; Bissell, D.M. Expression of variant fibronectins in wound healing: Cellular source and biological activity of the EIIIA segment in rat hepatic fibrogenesis. J. Cell Biol. 1994, 127, 2037-2048. [CrossRef]

132. Connolly, M.K.; Bedrosian, A.S.; Malhotra, A.; Henning, J.R.; Ibrahim, J.; Vera, V.; Cieza-Rubio, N.E.; Hassan, B.U.; Pachter, H.L.; Cohen, S.; et al. In Hepatic Fibrosis, Liver Sinusoidal Endothelial Cells Acquire Enhanced Immunogenicity. J. Immunol. 2010, 185, 2200-2208. [CrossRef] [PubMed]

133. Xie, G.; Wang, X.; Wang, L.; Wang, L.; Atkinson, R.D.; Kanel, G.C.; Gaarde, W.A.; Deleve, L.D. Role of differentiation of liver sinusoidal endothelial cells in progression and regression of hepatic fibrosis in rats. Gastroenterology 2012, 142, 918-927. e916. [CrossRef] [PubMed]

134. Papageorgiou, M.V.; Hadziyannis, E.; Tiniakos, D.; Georgiou, A.; Margariti, A.; Kostas, A.; Papatheodoridis, G.V. Serum levels of vascular endothelial growth factor in non-alcoholic fatty liver disease. Ann. Gastroenterol. 2017, 30, 209-216. [CrossRef] [PubMed]

135. Coulon, S.; Francque, S.; Colle, I.; Verrijken, A.; Blomme, B.; Heindryckx, F.; De Munter, S.; Prawitt, J.; Caron, S.; Staels, B.; et al. Evaluation of inflammatory and angiogenic factors in patients with non-alcoholic fatty liver disease. Cytokine 2012, 59, 442-449. [CrossRef]

136. Kitade, M.; Yoshiji, H.; Kojima, H.; Ikenaka, Y.; Noguchi, R.; Kaji, K.; Yoshii, J.; Yanase, K.; Namisaki, T.; Asada, K.; et al. Leptin-mediated neovascularization is a prerequisite for progression of nonalcoholic steatohepatitis in rats. Hepatology 2006, 44, 983-991. [CrossRef] [PubMed]

137. Ipsen, D.H.; Tveden-Nyborg, P. Extracellular Vesicles as Drivers of Non-Alcoholic Fatty Liver Disease: Small Particles with Big Impact. Biomedicines 2021, 9, 93. [CrossRef]

138. Chen, L.; Chen, R.J.; Velazquez, V.M.; Brigstock, D.R. Fibrogenic Signaling Is Suppressed in Hepatic Stellate Cells through Targeting of Connective Tissue Growth Factor (CCN2) by Cellular or Exosomal MicroRNA-199a-5p. Am. J. Pathol. 2016, 186, 2921-2933. [CrossRef]

139. Chen, L.; Chen, R.; Kemper, S.; Brigstock, D.R. Pathways of production and delivery of hepatocyte exosomes. J. Cell Commun. Signal 2018, 12, 343-357. [CrossRef]

140. Chen, L.; Chen, R.; Kemper, S.; Cong, M.; You, H.; Brigstock, D.R. Therapeutic effects of serum extracellular vesicles in liver fibrosis. J. Extracell Vesicles 2018, 7, 1461505. [CrossRef]

141. Oakley, F.; Meso, M.; Iredale, J.P.; Green, K.; Marek, C.J.; Zhou, X.; May, M.J.; Millward-Sadler, H.; Wright, M.C.; Mann, D.A. Inhibition of inhibitor of kappaB kinases stimulates hepatic stellate cell apoptosis and accelerated recovery from rat liver fibrosis. Gastroenterology 2005, 128, 108-120. [CrossRef]

142. Tao, L.L.; Cheng, Y.Y.; Ding, D.; Mei, S.; Xu, J.W.; Yu, J.; Ou-Yang, Q.; Deng, L.; Chen, Q.; Li, Q.Q.; et al. C/EBP- $\alpha$ ameliorates $\mathrm{CCl}(4)$-induced liver fibrosis in mice through promoting apoptosis of hepatic stellate cells with little apoptotic effect on hepatocytes in vitro and in vivo. Apoptosis 2012, 17, 492-502. [CrossRef] [PubMed]

143. Singh, H.D.; Otano, I.; Rombouts, K.; Singh, K.P.; Peppa, D.; Gill, U.S.; Böttcher, K.; Kennedy, P.T.F.; Oben, J.; Pinzani, M.; et al. TRAIL regulatory receptors constrain human hepatic stellate cell apoptosis. Sci. Rep. 2017, 7, 5514. [CrossRef]

144. Guo, Z.; Li, D.; Peng, H.; Kang, J.; Jiang, X.; Xie, X.; Sun, D.; Jiang, H. Specific hepatic stellate cell-penetrating peptide targeted delivery of a KLA peptide reduces collagen accumulation by inducing apoptosis. J. Drug Target 2017, 25, 715-723. [CrossRef] [PubMed]

145. Anstee, Q.M.; Neuschwander-Tetri, B.A.; Wong, V.W.; Abdelmalek, M.F.; Younossi, Z.M.; Yuan, J.; Pecoraro, M.L.; Seyedkazemi, S.; Fischer, L.; Bedossa, P.; et al. Cenicriviroc for the treatment of liver fibrosis in adults with nonalcoholic steatohepatitis: AURORA Phase 3 study design. Contemp. Clin. Trials 2020, 89, 105922. [CrossRef] [PubMed] 
146. Friedman, S.L.; Ratziu, V.; Harrison, S.A.; Abdelmalek, M.F.; Aithal, G.P.; Caballeria, J.; Francque, S.; Farrell, G.; Kowdley, K.V.; Craxi, A.; et al. A randomized, placebo-controlled trial of cenicriviroc for treatment of nonalcoholic steatohepatitis with fibrosis. Hepatology 2018, 67, 1754-1767. [CrossRef]

147. Ratziu, V.; Sanyal, A.; Harrison, S.A.; Wong, V.W.; Francque, S.; Goodman, Z.; Aithal, G.P.; Kowdley, K.V.; Seyedkazemi, S.; Fischer, L.; et al. Cenicriviroc Treatment for Adults With Nonalcoholic Steatohepatitis and Fibrosis: Final Analysis of the Phase $2 b$ CENTAUR Study. Hepatology 2020, 72, 892-905. [CrossRef] [PubMed]

148. Kruger, A.J.; Fuchs, B.C.; Masia, R.; Holmes, J.A.; Salloum, S.; Sojoodi, M.; Ferreira, D.S.; Rutledge, S.M.; Caravan, P.; Alatrakchi, N.; et al. Prolonged cenicriviroc therapy reduces hepatic fibrosis despite steatohepatitis in a diet-induced mouse model of nonalcoholic steatohepatitis. Hepatol. Commun. 2018, 2, 529-545. [CrossRef]

149. Hayakawa, R.; Hayakawa, T.; Takeda, K.; Ichijo, H. Therapeutic targets in the ASK1-dependent stress signaling pathways. Proc. Jpn. Acad. Ser. B Phys. Biol. Sci. 2012, 88, 434-453. [CrossRef]

150. Harrison, S.A.; Wong, V.W.; Okanoue, T.; Bzowej, N.; Vuppalanchi, R.; Younes, Z.; Kohli, A.; Sarin, S.; Caldwell, S.H.; Alkhouri, N.; et al. Selonsertib for patients with bridging fibrosis or compensated cirrhosis due to NASH: Results from randomized phase III STELLAR trials. J. Hepatol. 2020, 73, 26-39. [CrossRef]

151. Belfort, R.; Harrison, S.A.; Brown, K.; Darland, C.; Finch, J.; Hardies, J.; Balas, B.; Gastaldelli, A.; Tio, F.; Pulcini, J.; et al. A placebo-controlled trial of pioglitazone in subjects with nonalcoholic steatohepatitis. N. Engl. J. Med. 2006, 355, $2297-2307$. [CrossRef]

152. Sanyal, A.J.; Chalasani, N.; Kowdley, K.V.; McCullough, A.; Diehl, A.M.; Bass, N.M.; Neuschwander-Tetri, B.A.; Lavine, J.E.; Tonascia, J.; Unalp, A.; et al. Pioglitazone, vitamin E, or placebo for nonalcoholic steatohepatitis. N. Engl. J. Med. 2010, 362, 1675-1685. [CrossRef] [PubMed]

153. Ratziu, V.; Harrison, S.A.; Francque, S.; Bedossa, P.; Lehert, P.; Serfaty, L.; Romero-Gomez, M.; Boursier, J.; Abdelmalek, M.; Caldwell, S.; et al. Elafibranor, an Agonist of the Peroxisome Proliferator-Activated Receptor-alpha and -delta, Induces Resolution of Nonalcoholic Steatohepatitis Without Fibrosis Worsening. Gastroenterology 2016, 150, 1147-1159.e1145. [CrossRef] [PubMed]

154. Francque, S.; Bedossa, P.; Ratziu, V.; Anstee, Q.; Bugianesi, E.; Sanyal, A.; Loomba, R.; Harrison, S.A.; Balabanska, R.I.; Mateva, L. The panPPAR agonist lanifibranor induces both resolution of NASH and regression of fibrosis after 24 weeks of treatment in non-cirrhotic nash: Results of the NATIVE phase $2 \mathrm{~b}$ trial. Hepatology 2020, 72, 9A-11A.

155. Mudaliar, S.; Henry, R.R.; Sanyal, A.J.; Morrow, L.; Marschall, H.U.; Kipnes, M.; Adorini, L.; Sciacca, C.I.; Clopton, P.; Castelloe, E.; et al. Efficacy and safety of the farnesoid $X$ receptor agonist obeticholic acid in patients with type 2 diabetes and nonalcoholic fatty liver disease. Gastroenterology 2013, 145, 574-582.e571. [CrossRef]

156. Neuschwander-Tetri, B.A.; Loomba, R.; Sanyal, A.J.; Lavine, J.E.; Van Natta, M.L.; Abdelmalek, M.F.; Chalasani, N.; Dasarathy, S.; Diehl, A.M.; Hameed, B.; et al. Farnesoid X nuclear receptor ligand obeticholic acid for non-cirrhotic, non-alcoholic steatohepatitis (FLINT): A multicentre, randomised, placebo-controlled trial. Lancet 2015, 385, 956-965. [CrossRef]

157. Younossi, Z.M.; Ratziu, V.; Loomba, R.; Rinella, M.; Anstee, Q.M.; Goodman, Z.; Bedossa, P.; Geier, A.; Beckebaum, S.; Newsome, P.N.; et al. Obeticholic acid for the treatment of non-alcoholic steatohepatitis: Interim analysis from a multicentre, randomised, placebo-controlled phase 3 trial. Lancet 2019, 394, 2184-2196. [CrossRef] 